\title{
TANTALUS UNBOUND: GOVERNMENT POLICY AND INNOVATION IN CANADA
}

\author{
Professor Jeffrey G. Maclntosh \\ Toronto Stock Exchange Professor of Capital Markets \\ Faculty of Law, University of Toronto
}

\section{SUMMARY}

The future of the western industrialized economies, including Canada, depends on healthy and innovative high-tech sectors. In 2010, this realization spurred the Canadian government to commission a blue-ribbon panel charged with assessing the state of programs designed to support business and commercially oriented research and development. The resultant Jenkins Report contains many useful recommendations aimed at consolidating disparate offerings, measuring existing initiatives' performance and fostering federal-provincial cooperation to improve programs' impact on the tech sector. However, the Report erred in overlooking the squandering of government resources on tax subsidies to investors in Labour-Sponsored Venture Capital Corporations (LSVCCs) - union-sponsored specialized mutual funds meant to promote the development of high-growth small and mediums-sized businesses - which are far outperformed by the private sector and often waste capital better used elsewhere. It is also unduly harsh on the federal Scientific Research and Experimental Development Tax Credit, which is critical to the early-stage start-ups that give rise to high-tech giants. In judiciously assessing the Jenkins Report's recommendations and offering alternatives, this paper serves as a much-needed corrective, offering policy makers clear guidance in securing Canada's economic future. 


\section{PART I: INTRODUCTION}

It has become a commonplace to posit that the future of the western industrialized economies, including Canada, is closely tied to the health of the knowledge-based industries - or the hightechnology sectors of the economy. Moreover, a key component of a healthy high-technology sector is innovation, which includes a spectrum of activities running all the way from relatively modest improvements to existing technologies through to the invention of disruptive or radically new technologies. Many nations are currently engaged in an earnest examination of the ways in which governments can play a role in fostering innovation within their national borders; Canada is no exception. In October 2010, the federal government commissioned a blue-ribbon panel, under the chairmanship of Tom Jenkins, "to conduct an assessment of key programs within the government's portfolio of initiatives in support of business and commercially oriented R\&D," including both direct and indirect governmental support. The committee was instructed to make revenue-neutral recommendations, so that all recommendations for additional spending were to be offset by matching recommendations for reductions in other areas.

The Jenkins Report, ${ }^{l}$ delivered in October 2011, is indeed an important milestone in the examination of governmental funding of innovation in Canada. The purpose of this paper is to comment on those recommendations of the committee, which appear to be problematic. These include the panel's recommendation to scale back the Scientific Research and Experimental Development (SR\&ED) tax credit, and to devote the resulting savings to the enhancement of direct funding programs. In addition, I address an issue largely overlooked in the Jenkins Report: the squandering of both federal and provincial resources on tax subsidies to the largely unsuccessful Labour-Sponsored Venture Capital Corporations (LSVCCs).

Before proceeding to those aspects of the report, however, it would be a disservice to overlook the report's many useful recommendations. In particular, the report suggests that performance metrics be formulated for the evaluation of the many disparate offerings currently under the federal umbrella. ${ }^{2}$ It also sensibly proposes that the large menu of disconnected and often obscure federal programs be rationalized and consolidated. As the committee opines, this will furnish an opportunity for a comprehensive review of the efficacy of the many different programs, in addition to exploiting economies of scale in the delivery of government support. The committee further suggests that all federal programs be administered by an entity styled the Industrial Research and Innovation Council (IRIC). IRIC would play a key role in reviewing, consolidating and administering the various programs. It would also furnish entrepreneurs, often befuddled and perplexed by the disparate and often obscure menu of offerings, with userfriendlier one-stop shopping.

The report also notes the extensive overlaps between various federal and provincial programs, and wisely exhorts the federal government to "engage in a dialogue with the provinces to improve coordination and impact." It aptly opines that business innovation should be "one of the core objectives of procurement." As the American experience attests, the artful use of government procurement to support innovation is potentially one of the most potent tools in the government's arsenal. ${ }^{3}$

1 Innovation Canada: A Call to Action (Ottawa: Publishing and Depository Services, Public Works and Government Services Canada, 2011) (hereafter the Jenkins Report), expert panel commissioned by the federal government to review federal support for research and development, under the chairmanship of Tom Jenkins.

2 The committee rejects different standards for regional assistance programs. See Jenkins Report, p. 4-2. This is, in effect, a rejection of regional assistance as a distinct goal of government assistance, at least where innovation is concerned. In this, I concur.

3 See e.g., Michael Belfiore, The Department of Mad Scientists (New York: Harper, 2009). 
In what follows, Part II of the paper briefly reviews the perilous state of business innovation in Canada. Part III suggests that both federal and provincial governments end their wasteful subsidies of the LSVCCs. In Parts IV and V, I critically review the Jenkins Committee's recommendations regarding the SR\&ED credit and the relative merits of direct and indirect assistance programs. I suggest that the Jenkins Committee's lack of faith in the efficacy of indirect funding via the SR\&ED program is misguided. While agreeing with the Jenkins Committee's focus on co-funding arrangements for the delivery of direct assistance, I also suggest that co-funding arrangements have little or no role to play in funding basic and applied research and early-stage commercialization efforts. Finally, in Part VI, I suggest a change to the federal taxation legislation that is designed to enhance the profitability of a sale of a technology business to a foreign strategic acquirer, boosting the prospective profitability of investment in early-stage businesses.

\section{PART II: THE PERILOUS STATE OF BUSINESS INNOVATION IN CANADA}

As indicated in the Jenkins Report, Canadian support for R\&D is high compared to most other countries in the world. ${ }^{4}$ Nonetheless, the thrust of the report is that Canada does not do well when it comes to commercializing research - a conclusion that echoes the findings of many other reports on innovation in Canada. ${ }^{5}$ The best evidence that this is the case resides in the anaemic growth in Canadian labour productivity over the past several decades. As stated in a report of the Canadian Council of Academies in 2009: ${ }^{6}$

Canada has a serious productivity growth problem. Since 1984, relative labour productivity in Canada's business sector has fallen from more than 90 percent of the U.S. level to about 76 percent in 2007. Over the 19852006 period, Canada's average labour productivity growth ranked 15th out of 18 comparator countries in the OECD.

The Jenkins Committee thus concludes that "Canada has a business innovation problem,"7 and that "Canada's sub-par productivity growth is largely attributable to relatively weak business innovation."

\footnotetext{
4 Jenkins Report, Figure 6.1, p. 6-2.

5 See e.g., Canadian Council of Academies, Innovation and Business Strategy: Why Canada Falls Short (2009), available at

http://www.scienceadvice.ca/uploads/eng/assessments\%20and\%20publications\%20and\%20news\%20releases/inno/(20 09-06-11)\%20innovation\%20report.pdf; Expert Panel on Commercialization, People and Excellence: The Heart of Successful Commercialization. Volume I: Final Report of the Expert Panel on Commercialization (Ottawa: Public Works and Government Services Canada: 2006); Expert Panel on Commercialization, People and Excellence: The Heart of Successful Commercialization. Volume II: Supporting Material, (Ottawa: Public Works and Government Services Canada: 2006); Council of Canadian Academies, The State of Science \& Technology in Canada (Ottawa: CCA; 2006).

6 See Canadian Council of Academies, supra, note 5. The Jenkins Committee concurred. See Jenkins Report, ch.1.

7 Jenkins Report, pp.2-3. See also p.2-4

8 Ibid
} 
This is not merely incidental to Canada's future. As low-skill high-labour content work migrates to offshore locales, Canada's future, like that of other developed countries, lies in the cultivation of the so-called knowledge-based industries. As the committee puts it, "countries around the world have recognized the importance of business innovation as the ultimate source of competitive advantage and increasing prosperity." Particularly as the federal government spends some $\$ 7$ billion per annum in an attempt to build an innovative economy, it is thus a matter of some urgency that the best forms of government support be identified and implemented, and inefficient or ineffective programs weeded out.

\section{PART III: THE LSVCC PROGRAMS}

\section{Overview}

The federal and provincial governments should follow Ontario's lead ${ }^{10}$ and terminate their support for Labour-Sponsored Venture Capital Corporations (LSVCCs). ${ }^{11}$

In Québec, LSVCCs are incorporated pursuant to special acts of the legislature. By contrast, both the federal government and a number of Canadian provinces have enacted legislation that allows any person to incorporate an LSVCC, in a manner similar to the incorporation of a commercial company under general incorporation legislation. ${ }^{2}$ In contrast to a commercial corporation, however, an LSVCC is a specialized form of mutual fund. It accepts capital contributions from individual investors resident in the province of incorporation (except for federally incorporated funds, which may accept contributions from residents of any province). Only individuals may contribute to an LSVCC, and these investors are far less sophisticated then the high-net-worth individuals and institutional investors who capitalize private VC funds. As in any mutual fund, the fund managers seek to invest the capital contributions in pursuit of profit (although, as discussed below, the Québec funds have pursued goals other than simple profit maximization). In theory, LSVCCs are supposed to promote the development of highgrowth small and medium-sized enterprises, and the fund must typically invest a stated percentage (usually 60 percent) of its capital contributions in such businesses.

Investors in LSVCCs receive generous tax subsidies. Matching tax credits of 15 percent are paid by the incorporating province and the federal government, for a total tax credit of 30 percent, on investments not exceeding $\$ 5,000$. Most contributions are equal to or less than $\$ 5,000$. Investors typically must hold the investment for at least eight years to earn the tax credits, although in Québec, investors must hold their shares until retirement.

9 Jenkins Report, pp.1-2.

10 Ontario announced in 2005 that it would gradually phase out the LSVCC tax credit. It will completely disappear in 2012. See http://www.rev.gov.on.ca/en/guides/itrp/lsif.html.

11 In Québec, LSVCCs are created by special Acts of the legislature. Elsewhere in Canada, anyone may incorporate an LSVCC so long as they have a union sponsor. The bulk of Canada's LSVCCs are incorporated in Ontario.

12 These attributes are reviewed in Douglas J. Cumming and Jeffrey G. MacIntosh, "Mutual Funds that Invest in Private Equity? An Analysis of Labour-Sponsored Investment Funds" (2007), 31 Cambridge J. Econ. 445, and F. Vaillancourt, "Labour-Sponsored Venture Capital Funds in Canada: Institutional Aspects, Tax Expenditure and Employment Creation", in P. Halpern, ed., Financing Innovative Enterprise in Canada (Calgary: University of Calgary Press, 2007) 571. 
An LSVCC must have a labour union sponsor. Sponsorships are usually secured by a promise to pay the union a percentage of the net asset value of the fund (usually less than one percent). This has given rise to the oft-quoted rent-a-union cognomen to describe the arrangement. The union sponsor receives a special class of shares that allows it to appoint a majority of the directors of the fund. It thus possesses de jure control of the fund. Despite this, the special class of shares held by the union is not entitled to receive any dividends or to participate in the assets of the fund on winding up. Thus, the union's economic interest is limited to its sponsorship fee.

Not surprisingly, LSVCCs are not in fact incorporated, promoted, or managed by the union. Rather, an outside management entity unconnected with the union will incorporate the fund and approach the union seeking sponsorship. In the typical arrangement, the union will either contractually or informally cede its power to nominate directors to the management entity, which will thus possess de jure control of the fund. This arrangement institutionalizes a perfectly self-perpetuating management structure in which the managers are effectively insulated from removal by the real owners of the fund - the individual investors who provide the capital.

LSVCC promoter/managers have often been bankers, recently graduated MBAs, or others with little or no experience in venture capital investing. This is troubling, since venture capital is a hands-on industry in which expertise comes from many hard years of experience with small, high-tech, potentially high-growth companies. ${ }^{13}$

While a private venture capital fund is usually organized as a limited partnership with a 10year lifespan, an LSVCC is organized as a corporation with perpetual existence. This exposes investors to the danger that, in the absence of an exit event, the fund will carry overvalued investments on its books virtually indefinitely. Should this occur, it can result in a serious overstatement of the fund's net asset value. Since new investors buy in at the net asset value, this effectively transfers wealth from new investors to older investors.

This governance structure achieves a virtually perfect separation between ownership and control. It is an open invitation to high agency costs and poor management. ${ }^{14}$ Because ownership is widely dispersed between a large number of investors, each of whom holds a small stake, collective action and free-rider problems would virtually guarantee that shareholders would exercise little or no oversight over management even if they were empowered to appoint a majority of directors. ${ }^{15}$

\footnotetext{
13 Cumming and MacIntosh, "Mutual Funds that Invest in Private Equity? An Analysis of Labour-Sponsored Investment Funds", ibid.; James A. Brander, Edward Egan and Thomas F. Hellmann, "Government Sponsored Venture Capital in Canada: Effects on Value Creation, Competition and Innovation", paper presented at the NBER Conference on International Differences in Entrepreneurship, held in Savannah, GA, February 1-2, 2008.

14 Cumming and MacIntosh, supra, note 12.

15 Ibid.
} 
LSVCCs have limitations on their investment activities that private funds are not subject to. For example, it is customary for the provincial incorporating legislation to require LSVCCs to invest only in firms with a majority of employees or net assets in the province of incorporation. Set against the background of Canada's relatively diminutive market, this can be a rather crippling limitation. The success of a high-growth firm will often depend on expanding the firm's customer base, marketing operations, and/or manufacturing facilities to other countries. However, the territorial limits on investments limit the extent to which LSVCCs can participate in foreign-directed expansion-stage financing for their portfolio companies.

In addition, capital contributions must be invested within stated periods of time following receipt (the so-called pacing requirements), failing which the fund's investors may lose their tax credits. These requirements were adopted in order to prevent funds from indefinitely sitting on uninvested reserves. Unfortunately, they have created a new problem: funds investing unwisely or on disadvantageous terms when investment deadlines approach.

Numerous papers document the poor performance of LSVCCs as an asset class. The largest, Solidarity, has a 20-year return that is just slightly more than half what one would have earned by continually rolling over 91-day treasury bills. ${ }^{16}$ This is representative of the performance of LSVCCs as an asset class through the decades of the 1980s and 90s, in which LSVCCs as a whole earned less than short-term t-bills. ${ }^{17}$ In fact, LSVCC managers actually appear to be value-destructive. The higher the proportion of a fund's assets in equity, the lower the fund's return. $^{18}$

Private venture capital fund managers charge a combination of a fixed fee, averaging about two percent of the net asset value of the fund, and carried interest, which is typically 20 percent or more of the increase in the value of the portfolio (usually payable only over and above a hurdle rate of return). Successful private managers make the lion's share of their profits from the carried interest; the fixed fee covers only the costs of administration. ${ }^{19}$ By contrast, while LSVCC managers also charge both fixed fees and carried interest, they earn most of their return in the form of fixed fees. These fees are greatly in excess of those charged by private fund managers, averaging about four percent, and in some cases exceeding 10 percent. LSVCC managers charge these high fixed fees both because the small size of LSVCC funds does not allow for the exploitation of economies of scale in administration, and because they do not generate sufficient increases in portfolio value to earn carried interest. ${ }^{20}$

\footnotetext{
16 See GlobeAdvisor.com, at http://www.theglobeandmail.com/globe-investor/funds-andetfs/funds/summary/?compareBench=6339\&FromMonth=10\&FromYear=1984\&ToMonth=12\&ToYear=2011\&id=28 $577 \&$ symbol=\&style=na_eq \&profile_type=ROB .

17 See e.g. Cumming and MacIntosh, supra, note 12.

18 Cumming and MacIntosh, supra, note 12.

19 William A. Sahlman, "The Structure and Governance of Venture Capital Organizations" (1990), 27 Journal of Financial Economics 506.

${ }^{20}$ Cumming and MacIntosh, supra, note 12.
} 
Comparative returns data for LSVCCs and private funds are difficult to obtain. The Canadian Venture Capital Association (CVCA) has never published any returns data that segregate LSVCCs from other funds. ${ }^{21}$ Recently published CVCA survey returns data ${ }^{22}$ covering the 2001-2011 period segregates the sample of respondent firms into "Captive/Evergreen" funds and "Private Independent Funds." According to the CVCA, the captive/evergreen category represents "a broad constituency which includes Captive and Retail Fund managers, Corporate subsidiaries and other industry and government agencies [sic]." 23 This category thus digests all public, private, and hybrid venture capital funds other than private independent funds. It reports returns on a gross basis, versus a net basis for private independent funds. ${ }^{24}$ In addition, it calculates returns for investee companies only, rather than returns on the fund's entire portfolio of assets (versus returns to investors for private independent funds). For all of these reasons, a comparison between returns realized by captive/evergreen funds and private independent funds sheds little light on the comparative performance of LSVCC and private independent funds.

It is noteworthy, however, that the CVCA reports the net 10-year return of private independent funds to be -3.1 percent, versus a gross return of -2.3 percent for captive/evergreen funds. If a notional three percent management fee is deducted from the gross returns of captive/evergreen funds, ${ }^{25}$ the aggregate performance of these funds lags that of private independent funds by 2.2 percent over the past 10 years. There is reason to believe, however, that the performance

${ }^{21}$ Early performance studies, reporting on fiscal 2001-2004, lump all funds together in a single category. These studies are potentially misleading for at least two reasons. First, they compute performance for portfolio holdings only and do not take into account the influence of cash holdings or other non-portfolio assets within an entity. See http://www.cvca.ca/files/Resources/2001_Performance_Study.pdf. Since LSVCC funds hold significant portions of their assets in cash, the overall returns to venture investing are overstated. Second, these studies report gross, rather than net returns. They therefore fail to take into account the negative effect on overall performance of the high management fees charged by LSVCC funds. For fiscal 2005 and going forward, the CVCA switched to reporting returns on a net basis. However, the methodology for doing so differs for different fund types. For private independent funds "the net returns are calculated from the cash flows between funds and their outside investors." See http://www.cvca.ca/files/Resources/CVCA_Press_Release_Performance_Study_December_2005_Final.pdf, note 9. However, for all other funds, "the returns are based on the cash flows between the investment fund and the portfolio company" with a synthetic management fee of 2.5 percent and carried interest of 20 percent on the increase in value of the portfolio. Ibid. Since LSVCC funds retain high cash balances and other non-venture assets, this gives an inflated picture of LSVCC returns. A further change in methodology occurred in 2008, in which captive/evergreen funds were reported separately from private independent funds, with the captive/evergreen fund category including all funds save for private independent funds. This methodology has been carried through to the most recent report (covering fiscal 2010) and is discussed immediately following.

22 See CVCA, "Canadian Venture Capital \& Private Equity Industry: Performance Data - Captive/Evergreen Funds, December 13, 2011, available at http://www.cvca.ca/files/News/Q2_11_CVCA_Performance_Public_Release_Captive.pdf.

23 See "Canadian Venture Capital \& Private Equity Industry: Performance Data - Captive/Evergreen Funds", May 28, 2009, available at http://www.cvca.ca/files/Downloads/Q4_08_CVCA_Performance_Public_Release_FINAL_CAPTIVE.pdf.

24 See CVCA, "Canadian Venture Capital \& Private Equity Industry: Performance Data - Private Independent Funds", December 13, 2011, available at http://www.cvca.ca/files/News/Q2_11_CVCA_Performance_Public_Release_Private_Independent.pdf

${ }^{25}$ This is the same percentage used by Hellman and Schure in attempting to put the returns of LSVCCs and captive/evergreen funds on a similar footing for direct comparison. See Thomas Hellman and Paul Schure, "An Evaluation of the Venture Capital Program in British Columbia", Ministry of Small Business, Technology, and Economic Development, British Columbia, June, 2011. It is likely to understate the aggregate of management fees, since it fails to account for the carried interest that would have been deducted from returns by funds experiencing positive returns, had they been set up as private independent funds. 
differential between LSVCC and private independent funds is greater than this. Using a dataset covering the period from 2001 to 2009, Hellman and Schure ${ }^{26}$ compare the performance of British Columbia-based retail funds with the performance of captive/evergreen funds, and find that the captive/evergreen funds outperformed their sample of retail funds. ${ }^{27}$ This suggests that, if LSVCC funds were segregated from the other funds that make up the CVCA's captive/evergreen category, they would underperform private independent funds by something in excess of the overall captive/evergreen's underperformance of 2.2 percent.

Perhaps the most persuasive evidence, however, that LSVCCs underperform private independent funds arises from a paper by Brander et al. ${ }^{28}$ Using a dataset covering the period from 1992 to the first quarter of 1998, Brander et al. find that Canadian private independent venture capital funds outperformed LSVCCs by a large and statistically significant margin of 28-42 percent.

The dismal performance of LSVCCs reflects the lack of managerial expertise of LSVCC managers. At least in the case of the Québec LSVCCs, it also reflects the fact that the statutes creating LSVCCs impose multiple mandates that extend beyond generating profits for their investors. ${ }^{29}$ While funds outside of Québec have generally claimed that they focus on profitability, the Québec funds have eschewed profitability in favour of promoting regional development and labour union agendas. ${ }^{30}$

The Jenkins Committee observes that smaller funds are less likely to perform well, ${ }^{31}$ a concern also reflected in the BDC's Venture Capital Industry Review, published in early 2011. ${ }^{32}$ The $\mathrm{BDC}$ report presents data suggesting that the best performance is realized by funds in the range of \$200-300 million. ${ }^{33}$ The vast majority of LSVCCs have assets that are far less than this optimal size. Even the larger funds that initially appear to lie in the optimal range (or in excess thereof) divide their assets under administration into a large number of small funds, rather than pooling investment capital together in a single fund. Thus, any performance advantage that size might have conferred is lost.

${ }^{26}$ Hellman and Schure, ibid. The study evaluates the combined performance of the single LSVCC registered in BC (the Working Opportunity Fund, managed by GrowthWorks), and three BC-registered retail Venture Capital Corporations, with an analogous statutory framework to LSVCCs but for which the 30 percent tax credit is paid entirely by the BC government. See Hellman and Schure, p.10. I thus refer to these in the text as retail funds, rather than LSVCCs.

27

Ibid. at 38. It is difficult to evaluate the magnitude of the underperformance of LSVCC funds for a number of reasons. The captive/evergreen category itself includes LSVCC funds. Obviously, the inferior-performing LSVCCs would drag down the relative performance of the benchmark, understating the extent to which LSVCCs underperform captive/evergreen funds. In addition, the Working Opportunity Fund holds assets other than venture capital assets. Hellman and Schure report that in 2009 the Working Opportunity Fund held seven percent of its assets in bonds and 23 percent "in what boils down to the TSX Composite Index." Ibid. at 37.

28 J.A. Brander, R. Amit, and W. Antweiler, "Venture capital syndication: improved venture selection versus the valueadded hypothesis' (2002), 11 Journal of Economics and Management Strategy 423.

29 See e.g., Cumming and MacIntosh, supra, note 12.

30 D. Osborne and D. Sandler, "A Tax Expenditure Analysis of Labour-Sponsored Venture Capital Corporations." (1998), 46 Canadian Tax Journal 499; Douglas J. Cumming and Jeffrey G. MacIntosh, "Venture Capital Exits in Canada and the United States" (2003), 53 University of Toronto Law Journal 101. This is discussed further below.

31 Jenkins Report, pp. 7-15 to 7-17.

32 BDC, Venture Capital Industry Review (BDC, February 2011).

33 Ibid. at 13 . 
Thus, for example, Covington manages in excess of $\$ 300$ million in capital. However, this is divided between five master funds, most of which are in turn composed of a number of smaller funds. By way of illustration, one of the master funds - the Covington Venture Fund - is itself composed of five constituent funds. ${ }^{34}$

Similarly, the $\$ 430$ million in capital managed by GrowthWorks is divided between the Working Opportunity Fund, the GrowthWorks Canadian Fund (no longer available for purchase because of illiquidity), the GrowthWorks Commercialization Fund, and the GrowthWorks Atlantic Venture Fund. In turn, each of these is composed of a number of constituent funds. The Atlantic Venture fund, for example, is divided into a Balanced Series, with \$25 million in net assets, the GIC Series, with \$1.29 million in net assets, the Growth Series, with \$0.95 million in assets, and the Financial Services Series, with $\$ 1.4$ million in net assets. The largest of the GrowthWorks funds - the GrowthWorks Canadian fund, with some \$224 million in aggregate assets - is divided into 19 different constituent funds. Needless to say, none of these constituent funds falls within the optimal size range noted in the BDC report.

The comparatively poor returns of small funds are due to a number of factors. For one, it often forces the fund to make an initial investment that is smaller than the investee firm requires, inhibiting growth. It can also interfere with the fund's ability to attract credible and experienced syndication partners, and prevents the fund from exploiting economies of scale in administration. Finally, it inhibits the extent to which a fund can make follow-on investments, without which the investee firm may flounder or expire.

As noted in the BDC report on venture capital in Canada, the problem of small fund size is not unique to LSVCCs. ${ }^{35}$ However, the LSVCC programs encourage the division of capital pools into small funds for marketing purposes, in order to appeal to constituencies of investors with different risk/return preferences. Thus, for example, the GrowthWorks Canadian Fund markets a Canadian \& Merger Series, a GIC Series, a Growth Series, an Income Series, a Financial Services Series, and a Diversified and CMDF Reinvestment Series. ${ }^{36}$

The LSVCCs would be less inclined to relentlessly sub-divide their portfolios into seemingly endless varieties of offerings if the negative effect that this has on returns inhibited fund raising. However, as the following discussion makes clear, the returns experienced by LSVCC funds have little or no influence on their ability to raise new capital.

Investments in LSVCCs are tax-driven. As noted, generous tax credits are paid on investments of up to $\$ 5,000$, and most investments are of this amount or less. Potent evidence of the taxdriven nature of the LSVCCs is that, contrary to the typical experience with mutual funds, the ability of a given LSVCC to raise funds from retail investors is disconnected from its rate of return. ${ }^{37}$ This is reflective of the fact that LSVCCs are invariably marketed (and purchased) on the basis of the tax credits. This can be seen by perusing various LSVCC websites, which typically offer either little or selective historical data on returns. The selling point is invariably the tax credits.

\footnotetext{
34 The Series I, II, III funds: the Series IV fund; the Series V fund; the Series VI fund; and the Series VII, VIII, IX fund. See Covington Group of Funds, 2011 Annual Report.

35 BDC, Venture Capital Industry Review (BDC, February 2011), p.13.

36 See GrowthWorks Canadian Fund, 2011 Annual Financial Statements.

37 Cumming and MacIntosh, supra, note 30. See also BDC, Venture Capital Industry Review (BDC, February 2011), p.17.
} 
A primary motivation for the generous LSVCC tax credits has been to bulk up the Canadian venture capital industry. However, the evidence is that they have failed to do so. LSVCC funds grew rapidly in the 1990s, to the point where they constituted a large percentage of Canadian VC capital under administration. Nonetheless, the evidence is that this growth came at the expense of more efficient private funds. ${ }^{38}$ This crowding-out phenomenon is a consequence of two factors. First, the tax credits paid to LSVCC investors give the LSVCC funds a lower cost of capital than private funds. The LSVCCs have therefore been able to outbid private VCs in respect of promising investments. Second, the large sums of capital under administration by LSVCCs have made this crowding-out phenomenon pervasive. This has diminished the returns of private VCs and played a key role in driving pension funds and other furnishers of capital to private funds to the sidelines. ${ }^{39}$

\section{Are the Québec-Based Tax-Subsidized Funds Really Venture Capital?}

In this section I discuss three large Québec-based funds that receive generous tax subsidies. Two are LSVCCs (Fonds de solidarité FTQ, and Fondaction), while the third - Desjardins Venture Capital - is not. Investors in Desjardins, however, receive a generous tax credit from the province of Québec that is about the same as the combined tax credit paid to LSVCC investors by the province of Québec and the federal government. While all of these three funds are nominally venture capital funds, they are in fact nothing of the sort.

\section{FONDS DE SOLIDARITÉ FTQ}

The single largest venture capital fund in Canada is the Fonds de solidarité FTQ (hereafter Solidarity). Solidarity's audited financial statements as of May $2011^{40}$ indicate that of total assets of $\$ 8.8$ billion, only $\$ 4.27$ billion - about half - are Development Capital Assets. The balance of $\$ 4.2$ billion (so-called Other Investments) is invested in shares in public companies ( $\$ 1.5$ billion), hedge fund units ( $\$ 216$ million), bonds ( $\$ 2.30$ billion), and money-market instruments ( $\$ 154$ million). Of the whopping $\$ 2.30$ billion in bonds, more than two-thirds (69 percent) are bonds of governments and government agencies, the majority of which have maturities ranging from five to 30 years. None of these Other Investments could remotely be called venture capital.

Does this, nonetheless, indicate that $\$ 4.27$ billion - the Development Capital Assets (DCA) - are venture capital? Not at all. True venture capital investments are, virtually by definition, investments in private companies. However, unlisted shares and units comprise only 49 percent of all DCA, or about 25 percent of total fund assets. ${ }^{41}$ That puts a rough upper bound on the proportion of Solidarity assets that are true venture capital. ${ }^{42}$

\footnotetext{
38 Douglas J. Cumming and Jeffrey G. MacIntosh, "Crowding Out Private Equity: Canadian Evidence" (2006), $21 \mathrm{~J}$. Bus. Venturing 569.

39 Cumming and Macintosh, ibid; James A. Brander, Edward Egan and Thomas F. Hellmann, "Government Sponsored Venture Capital in Canada: Effects on Value Creation, Competition and Innovation", paper presented at the NBER Conference on International Differences in Entrepreneurship, held in Savannah, GA, February 1-2, 2008.

40 Fonds de solidarité FTQ, Financial Statements, 2011.

41 The balance is listed shares and units and both secured and unsecured loans, bonds, and advances.

42 The financial statements do not indicate what proportion of debt instruments are convertible. If there is a significant proportion, the ceiling could be higher than 50 percent.
} 
However, further inspection reveals that the figure is almost certainly much smaller. Private venture capital investments are overwhelmingly in technology companies. But of the $\$ 4.27$ billion of Solidarity invested in DCA, only 20.7 percent are investments in technology, when measured at cost, ${ }^{43}$ and 15.3 percent when measured at market value. ${ }^{44}$ Comparable or greater amounts are invested in each of several traditional industries, including manufacturing and primary extraction ( $\$ 1.07$ billion by cost, and $\$ 987$ million by market value), services and tourism ( $\$ 1.46$ billion by cost, and $\$ 1.7$ billion by market value), and regional or local and real estate funds ( $\$ 780$ million by cost, and $\$ 930$ million by market value).

Two other indicia typical of private capital investments are that they are equity ${ }^{45}$ investments made at a comparatively early stage of a company's existence. ${ }^{46}$ However, an unknown proportion (possibly as great as half) of the technology investments in Solidarity's portfolio are non-equity investments such as non-convertible debt instruments, credit facilities, project financing, and guarantees. ${ }^{47}$ Added to this, there is no way to tell what proportion of the technology investments are early- or expansion-stage investments; the overwhelming proportion may be later-stage technology investments. ${ }^{48}$ Making the generous assumption that half of the technology investments are true venture capital, only about 10 percent of DCA is venture capital, or about five of total fund assets.

It is probably more accurate to say that none of Solidarity's direct investments are venture capital. As outlined in Appendix A, the term venture capital describes a wide-ranging complex of agency relationships and incentive structures that extends well beyond the characteristics of the investee firms. Some of the key characteristics are as follows.

A private venture fund is typically operated as a limited partnership (LP) that is wound up after 10 years. The limited lifespan of the fund means that failed investments cannot indefinitely be carried (and concealed) on the balance sheet. At some point, all investments are exposed to the judgment of the market, creating an accurate accounting of the manager's performance over the life of the fund. This plays an important role in disciplining the venture managers.

The venture manager will typically retain 20 percent or more of the increase in the value of the fund's net assets (the carried interest). This supplies the VC manager with a potent incentive to create value.

\footnotetext{
$43 \$ 864,934,000$.

$44 \$ 652,459,000$

45 I include in equity any residual claim on the company's earnings stream (and assets on winding up), and any claim (such as convertible preferred shares or debt) that is convertible into a residual claim.

46 Venture capitalists do not typically invest at the very earliest stage (i.e., the seed stage) of a company's existence, which roughly encompasses the time from the initial idea to marketing the company's first products. Rather, venture capital investments are typically made in early- and expansion-stage companies, which roughly include companies that have already marketed their first commercial products to companies with demonstrated market traction that seek additional funds to expand production, development, distribution, and/or marketing.

47 See Fonds de solidarité FTQ, Financial Statements, 2011, Notes to Financial Statements, note 4 (Developmental Capital Investments), note 1 (defining funds committed but not disbursed) and note 2 (indicating that such investments may be in the form of a guarantee).

${ }^{48}$ Conversation with Éric Legault, Managing Partner, Teralys Capital.
} 
VC managers typically have an extended skill set (outlined in Appendices B and C) not possessed by any other type of equity investor save skilled business angels. They are also extremely active investors. Aside from representation on the board of directors, a VC manager will usually be in close contact with the firm's principals, supplying advice and direction on an informal basis, and will play a key role in shaping high-level strategy.

Even when not holding a majority stake, a VC (or syndicate of VCs) will carefully craft their contractual relationship with investee firms to give themselves the power to make or veto key decisions, hire and fire management, and ultimately to play a role similar to that of a controlling shareholder. These contracts are also designed to incentivize the entrepreneurs of investee firms, by requiring entrepreneur to earn their stake in the firm by meeting various performance metrics (so-called sweat equity), providing for repurchase options should the entrepreneurs leave the firm or not meet performance targets, or by other means.

Private VCs usually syndicate their investments. This increases the intellectual firepower brought to bear in the selection of investments, in addition to the quality and quantity of oversight during the term of the investment. ${ }^{49}$

Solidarity investments - like those of most other LSVCC funds - lack most or all of these factors. Unlike a private fund, Solidarity has a perpetual existence. Its investment managers are salaried employees with a limited stake in the success of the companies that they fund. Lacking the extended skill set of private investors, they contribute little to building value in the business. Even if they were to possess the contractual levers of private investors, lacking the appropriate skills, they would be unable to use them effectively to create value. In addition, relatively few of Solidarity's investments are syndicated, sacrificing the benefits of syndication noted above.

In fact, despite the "LSVCC" tag, Solidarity was never really intended to be a venture capital fund. The product of a deal between the Québec Federation of Labour and the government of Québec, the fund was designed to serve a multitude of purposes that have essentially nothing to do with venture capital. These include: encouraging blue collar workers in Québec to invest in small and medium-sized Québec businesses; allowing these workers to participate in the growth of the economy; giving workers a shareholder's perspective on running a business; promoting economic development in depressed regions of Québec; acting as a funding source of last resort to keep Québec businesses afloat in hard times; and supporting unionized enterprise and contributing to labour peace in Québec. What Solidarity was not created to do was to invest primarily in the type of firm favoured by private VCs: potentially high-return technology firms with commensurately high risk.

Solidarity's recent history is instructive. Precisely because its (limited) attempts to engage in venture capital have not succeeded, Solidarity has essentially vacated the field. It now places a small portion of its assets with Montreal-based private fund-of-funds manager Teralys. In turn, Teralys places the money with a selected group of private venture capital funds either operating in Québec, or investing in Québec-based companies.

49 While syndicates will usually designate a lead VC, the other members of the syndicate will also supply useful oversight and direction. 
Solidarity's decision to vacate the venture capital field and place a small portion of its funds with a private fund-of-funds manager has been matched by two other major governmental institutional investors in Québec: the Caisse de dépôt et placement du Québec and Investissement Québec. These three Québec governmental entities initially placed \$600 million with Teralys ${ }^{50}$ recently supplemented by an additional $\$ 700$ million. Assuming that Solidarity's share is $1 / 3$ of the aggregate commitment, that means that about $\$ 430$ million of Solidarity's portfolio is true venture capital. That constitutes about 5.2 percent of Solidarity's assets as of May 31, 2011.

\section{FONDACTION}

Solidarity is not the only legislatively created LSVCC in Québec. A second LSVCC, Fondaction, ${ }^{5 l}$ has similar multiple statutory objectives. Its prospectus states that:

Under the Act, the main functions of Fondaction are:

- to promote investments in enterprises by investing directly in order to create, maintain or protect jobs of by guaranteeing or standing surety for any obligation contracted by them;

- to foster the development of [eligible enterprises] by inviting working men and women and other community resources to participate in their development by subscribing for shares of the Fund;

- to develop the management skills of the working men and women in worker-controlled enterprises and facilitate their active involvement in the economic development of Québec;

- to help enterprises conform to environmental laws and regulations; to foster the development of environmental policies within enterprises. ${ }^{52}$

Needless to say, these objectives have very little to do with what may truly be called venture capital. Indeed, Fondaction's financial statements read very much like those of Solidarity. Of Fondaction's assets of $\$ 877.6$ million as of May 31, 2011, it would appear that, like Solidarity, no more than five percent is true venture capital.

50 http://www.teralyscapital.com/who-we-are, and conversation with Éric Legault, Managing Partner, Teralys Capital.

51 The full name is "Fondaction, le Fonds de développement de la Confédération des syndicats nationaux pour la coopération et l'emploi." Investors in Fondaction receive tax credits even more generous than those in Solidarity: a 25 percent provincial tax credit and a 15 percent federal tax credit, for a combined credit of 40 percent. As with Solidarity, investors must hold their shares until retirement.

52 "Simplified Prospectus Relating to the Offer of Class "A" Shares Series 1 and Series 2 of Fondaction, Le Fonds de Développement de la Confédération des Syndicats Nationaux pour la Coopération et l'Emploi”, December 20, 2011, available at http://www.fondaction.com/pdf/prospectus/2011PROSPECTUS\%20_ANG.pdf, p.1. Section 1.3 of the prospectus further states, inter alia, that the mission of Fondaction is "development of the management skills of the working men and women in worker-controlled enterprises and to facilitate their active involvement in the economic development of Québec." 


\section{DESJARDINS VENTURE CAPITAL}

As of December 31, 2010, Desjardins Venture Capital (DVC), a wholly owned subsidiary of the Desjardins Group, had \$1.04 billion under management. DVC is the asset manager for Desjardins Capital regional et cooperatif (DCR) ${ }^{53}$ whose dual mission is "promoting the economic development of Québec cooperatives and regions." ${ }^{54}$ To this end, a large part of its business activity consists of buying Québec businesses and turning them into worker cooperatives. Once again, the business of DCR is not in any sense true venture capital.

In fact, DCR's financial statements disclose that it had a higher proportion of its assets (57 percent) in "Other Investments" (bonds, money market instruments and preferred shares) than either Solidarity or Fondaction..$^{55}$ Of $\$ 955$ million average assets under administration in 2010, $\$ 86$ million, or nine percent, are identified as either "technological innovations" or "venture capital - health". However, as with other Québec governmental funds, we can have no confidence that all or perhaps any of this represents true venture capital. ${ }^{56}$

\section{Effect on Industry Statistics}

The Canadian Venture Capital Association (CVCA) maintains industry statistics on the state of venture capital in Canada. The CVCA classifies about 20-25 percent of Solidarity's assets as venture capital. ${ }^{57}$ This means that of the $\$ 14.9$ billion of venture capital that the CVCA indicated were under management in Canada in $2010,{ }^{58}$ Solidarity accounted for about \$1.6-2.0 billion. As indicated, a more accurate figure would be $\$ 430$ million. Thus, the CVCA overstates Solidarity's venture portfolio by some $\$ 1.17$ to $\$ 1.57$ billion.

For similar reasons, it would appear that the venture portfolios of Fondaction and DVC are overstated - the former by $\$ 131-175$ million, and the later (conservatively) by about $\$ 100$ million. The combined overstatement for Solidarity, Fondaction, and DVC is thus on the order of \$1.4-1.85 billion, or roughly 9.4-12.4 percent of the CVCA's portfolio of venture capital.

53 DVC also serves as investment manager for Desjardins-Innovatech S.E.C. and Capital croissance PME S.E.C. However, the latter is a subsidiary of DCR, and the former is a joint venture of DCR and the Québec government. Thus, for practical purposes, DVC has a single client - DCR.

542010 Annual Financial Report, Desjardins Capital regional et cooperatif, p.4. The report further states (at p.5):

The Company's mission is to:

- Contribute to Québec's economic development and take an active part in the growth of the following regions: Abitibi-Témiscamingue, Bas-Saint-Laurent, Côte-Nord, Gaspésie -Îles-de-la-Madeleine, Mauricie, Nord-duQuébec and Saguenay - Lac-Saint-Jean (the resource regions);

- Inject development capital into companies and cooperatives and provide expert advice to support their startup, growth and expansion; and

- Generate returns that will encourage shareholders to reinvest

55 DCR 2010 Annual Financial Report, p.13, available at http://www.capitalregional.com/En/references/documents/2010_Rapportfinancier_annuelANG.pdf).

56 These two categories together contributed 0.1 percent of DCR's gross return of 5.4 percent return in 2010, and -1 percent to its gross return of 5.5 percent in 2009. Ibid. p.11.

57 Conversion with Gilles Duruflé, Vice President of the CVCA.

58 http://www.cvca.ca/files/Downloads/2010_CVCA_Liquidity_2001-2010.pdf. 
This overstatement leads to a somewhat misleading picture of where Canada's venture capital industry stands on the world stage. For example, the 2009 Global Entrepreneurship Monitor ranks 31 countries on the percentage of GDP devoted to venture capital. ${ }^{59}$ Using the revised figures drops Canada from 8th to 12th place. Particularly given the importance of CVCA statistics in informing government policy, the government should urge the CVCA to restate their figures more consistently with the analysis indicated above.

\section{Implications for the Design of Government Programs Aimed at Fostering Innovation}

Tax subsidized venture capital funds in Québec have very little to do with either venture capital or promoting innovation. Rather, the roughly $\$ 1.85$ billion in tax credits paid by the federal government to Solidarity and Fondaction investors ${ }^{60}$ has mostly subsidized investments in: i) publicly traded securities, bonds (the majority of which are government bonds), credit facilities and other loans, hedge funds, money-market instruments, and derivative securities; ii) regional development; iii) companies in traditional industries that have nothing to do with the development of new technologies or innovation. The tax credits paid by the federal government effectively represent a hidden equalization payment directed to Québec from the rest of Canada. The beneficiaries of this equalization payment are retail investors situated in Québec, Québec businesses - particularly in outlying regions, and the Québec Federation of Labour (Solidarity's union sponsor).

\section{Are Other (Non-Québec) LSVCCs Really Venture Capital?}

Outside of Québec, any person may incorporate an LSVCC under provincial legislation, as long as the fund has a union sponsor. The majority of non-Québec LSVCCs have been incorporated in Ontario. Like their Québec counterparts, these LSVCCs earn a combined 30 percent provincial and federal tax credit - although in 2005, Ontario announced that it would be phasing out its tax credit. It will fully disappear in $2012 .{ }^{61}$

59 John Bosma and Jonathan Levie, "Global Entrepreneurship Monitor: 2009 Report." Canada did not participate in the 2010 survey.

60 At first pass, a rough lower bound on the tax credits paid to Solidarity investors is $\$ 1.2$ billion - or 15 percent of the current portfolio of $\$ 8$ billion in assets. While the federal government did not pay tax credits until May of 1985 (following the second year of operation), the assets of Solidarity were only \$14 million after its first two years of operation. See http://www.caledonia.org.uk/papers/Québec-solidarity-fund.pdf (data reportedly derived from Solidarity Annual Report 2003). Thus, the failure to pay tax credits in the first two years of operation has a de minimis impact on the estimated lower bound. This estimate is unquestionably too low, however, given that current assets under management do not represent all contributions, since some contributors have reached the age of retirement and cashed out. Wikipedia reports that the total investments since inception are $\$ 10.8$ billion. See http://en.wikipedia.org/wiki/Fonds_de_solidarit\%C3\%A9_FTQ. This would establish a lower bound on the federal contribution of about \$1.62 billion. In addition, however, between 1985 and 1996, the federal government paid a tax credit of 20 percent. See Ayi Ayayi, "Good News, Bad News: Lessons Learned from the Canadian Labour-Sponsored Venture Capital Corporations", presented at CESifo conference "Venture Capital, Entrepreneurship, and Public Policy," CESifo Conference Centre, Munich, 22-23 November 2002. In June of 1996, Solidarity's total assets were $\$ 1.76$ billion. See http://www.25ansfondsftq.com/PDFs/rapportannuelfonds96.pdf. Thus, a more accurate estimate of the federal tax expenditure is $\$ 1.7$ billion ( $\$ 350$ million between 1985 and 1996, and $\$ 1.35$ billion between 1996 and the present).

With respect to Fondaction, the fund has been in existence for only 10 years. For this reason, the number of redemptions effected will be small (since investors normally have to wait until retirement to cash out), and a fair estimate of the federal tax credits is thus about $\$ 150$ million.

${ }^{61}$ See http://www.rev.gov.on.ca/en/guides/itrp/lsif.html. 
At least superficially, non-Québec LSVCCs ("NQ" funds) more closely resemble private LSVCCs. For example, like their private counterparts, the managers receive a fixed fee that nominally covers administrative expenses, in addition to carried interest based on the increase in the net asset value of the portfolio. The similarity with private funds, however, is mostly cosmetic. Although NQ managers have portfolio assets that more closely resemble those of private managers, they nonetheless lack the skill set of private venture managers and have largely been incapable of growing their retinue of portfolio companies into larger companies, generating weak or even negative returns. ${ }^{62}$ Because of their lower cost of capital, they have driven more efficiently run private venture capital firms from the market.

The returns realized by the NQ funds are not materially different from those of the Québec funds. GrowthWorks Canadian Fund, one of the GrowthWorks-managed stable of funds and one of the largest NQ funds (with gross assets of approximately $\$ 225$ million $^{63}$ ) is illustrative. The top-performing fund in the GrowthWorks Canadian Fund group of funds in the three years preceding February 2012 realized a return of 8.7 percent, ${ }^{64}$ compared to 27.3 percent for the S\&P/TSX Index ${ }^{65}$ and 30.1 percent for the Astra Canadian Small Cap Equity Index. ${ }^{66}$ The arithmetic mean return of GrowthWorks Canadian Fund's 29 funds with three-year returns data is -6.84 percent, yielding a whopping -34.1 percent when compared to the S\&P/TSX Index, and -36.9 percent when compared to the Astra Canadian Small Cap Equity Index.

The management expense ratios for GrowthWorks' funds are equally shocking, ranging from 3.85 percent to an astonishing 7.64 percent, with an arithmetic average of 5.66 percent. ${ }^{67}$

GrowthWorks Canadian Fund's woes go well beyond poor returns, however. With insufficient liquidity to meet investor demand for redemptions, it suspended its redemptions in November 2011, indicating that it would entertain requests for redemptions on a semi-annual basis, but leaving it to the board of directors to determine the quantity of redemptions at each semiannual interval. ${ }^{68}$

62 Cumming and MacIntosh, supra, note 12.

63 See GrowthWorks Canadian Valuation Report, available at http://www.sedar.com/GetFile.do?\&lang=EN\&docClass=5\&issuerNo=00009732\&fileName=/csfsprod/data125/filing s/01835479/00000001/y\%3A\%5CWeb_Documents\%5CRADAR\%5CE3\%5CE3GR0BB7\%5C29NO11275\%5CValua tionReport_jaj.pdf.

${ }^{64}$ GrowthWorks Commercialization 09. See http://www.morningstar.ca/globalhome/industry/fundtable.asp?quick=finder\&currview=2\&Sponsor_ID=158137\&Fun d_Type $=* \&$ RRSP $=* \&$ load_struct $=* \&$ total_asset_value $=* \&$ Expense_Ratio $=* \&$ Rating_3y $=* \&$ sort $1=$ R3y $\&$ findord $=\&$ top $=50 \&$ Submit $2=$ Show + Funds \&nodata $=0$. Morningstar's figures include the performance of the Working Opportunity Funds, which are managed by GrowthWorks (even though Working Opportunity files separate financial statements and reports with the securities regulators).

65 http://www.theglobeandmail.com/globe-investor/markets/stocks/chart/?q=tsx-I.

66 See http://www.theglobeandmail.com/globe-investor/funds-andetfs/funds/summary/?compareBench=\&FromMonth=2\&FromYear=2009\&ToMonth=2\&ToYear=2012\&id=55230\&sy mbol=SSQ115\&style=na_eq \&profile_type=ROB .

${ }^{67} \mathrm{See}$

http://www.morningstar.ca/globalhome/industry/fundtable.asp?quick=finder\&currview=2\&Sponsor_ID=158137\&Fun d_Type $=* \&$ RRSP $=* \&$ load_struct $=* \&$ total_asset_value $=* \&$ Expense_Ratio $=* \&$ Rating_3y $=* \&$ sort $1=$ Er $\&$ findord $=\&$ to $\mathrm{p}=50 \&$ Submit $2=$ Show + Funds $\&$ nodata $=0$.

68 See http://www.growthworks.ca/newsPDF/GW\%20Cdn\%20Press\%20Release $\% 20$ -

$\% 20$ RMP $\% 20$ (issued\%20Nov\%2010,\%202011).pdf. 
Overall, some of the GrowthWorks-managed portfolio of funds consists of assets that are similar to those targeted by private venture capitalists. ${ }^{69}$ However, others could only loosely be styled venture capital. ${ }^{70}$

If, as the BDC states, the Canadian venture capital industry is broken, the first step that must be taken to repair the damage is to end the LSVCC subsidies, and allow private venture capitalists to retake the Canadian venture capital landscape. In order to allow for an orderly wind-down of the LSVCC funds, the tax credits should be phased out over a period of several years, as Ontario has done. ${ }^{71}$

\section{Looming Disasters in the Works?}

Most private funds are organized as limited partnerships with a 10-year lifespan. These funds typically invest their committed capital in the first three or four years of the fund's life. In the balance of the 10-year lifespan, the venture capitalist's energies are devoted to husbanding and nurturing their entrepreneurial firms so that a profitable exit may be effected prior to the fund's termination date. Importantly, once the 10-year horizon is reached, all fund assets must be sold, and the proceeds distributed to investors. ${ }^{72}$ The 10 -year horizon thus serves an effective disciplinary function. While the $\mathrm{VC}$ might be able to carry overvalued investments on its balance sheet for years, when its lifespan expires, it simply cannot hide from the market's disinterested verdict on the true worth of its portfolio investments.

By contrast, LSVCCs are organized as corporations with an unlimited lifespan. This means that, under normal accounting rules, as long as an investee firm does not go bankrupt, it can be carried on the fund's balance sheet at cost virtually indefinitely, no matter its real market value. $^{73}$

The collapse of Manitoba's LSVCC Crocus Fund is illustrative. Investment valuations were initially conducted by staff, which then forwarded valuation recommendations to a Valuation Sub-committee of the Board. Even though the committee was assisted by an external valuation expert, however, many of Crocus's investments in non-traded companies were carried on the

69 For example, the assets of the Venture Series, by category, are as follows: Information Technology 55.3 percent; Life Sciences 25.9 percent; Cleantech 15.9 percent; and Other 2.9 percent. In addition, like many private funds, many of the fund's investments are made at relatively early stages of development. The breakdown is: Seed/Pre-Clinical Stage 2.6 percent; Early/Clinical Stage 72.3 percent; Later Stage 25.1 percent.

See Working Opportunity Fund 2010 Annual Financial Statements, p.iv, available at http://www.sedar.com/GetFile.do?\&lang=EN\&docClass=5\&issuerNo=00025127\&fileName=/csfsprod/data116/filings /01720940/00000001/y\%3A\%5CWeb_Documents\%5CRADAR\%5CE3\%5CE3WO0BBB\%5C30MA11185\%5C1103 30AFS_jaj.pdf

70 Working Opportunity's Commercialization Series, for example, is heavily weighted toward later stage investments. Working Opportunity Fund 2010 Annual Financial Statements, ibid.

71 Ontario announced in 2005 that it would phase out its LSVCC tax credit by 2011. This was subsequently extended to 2012. There is obviously a balance to be struck between ending a program that, in net, has damaged venture capital markets, and not inflicting excessive losses on retail investors who have put money into the LSVCC programs.

${ }^{72}$ In some cases, rather than selling and distributing cash, the fund will distribute shares in its investee firms in kind.

73 This is a consequence of the usual accounting rule that, absent a subsequent market transaction, the value of an asset is shown on the balance sheet at historical cost. 
fund's books at serious overvalues for a period of years (with no adverse comment from the fund's auditor). ${ }^{74}$ After vigorously battling allegations related to overvaluations (including suing at least one newspaper making such an allegation), in late 2004 the board suspended trading in Crocus's shares and remitted the entire portfolio to an external valuation. When the dust settled, the restated value of the portfolio was about half the posted net asset value prior to the suspension of trading. Crocus ended up in insolvency proceedings. Its directors, underwritings, auditor, external valuation expert and others were the subject of a number of actions on behalf of its investors (all ultimately settled, many with substantial payouts). Its directors were also the subject of regulatory proceedings by the Manitoba Securities Commission (also ultimately settled). ${ }^{75}$ The behaviour of the fund's directors and its valuation practices were the subject of a scathing report by the Attorney General of Manitoba.

In response to this problem, Canadian securities regulators now require all labour-sponsored funds to secure an independent valuation of their portfolio investments in connection with the release of each set of annual financial statements. ${ }^{76}$ While this is a welcome regulatory development, it should not be understood to be a complete solution to the problem of overvaluation. The valuation of private companies is never an easy task. Particularly for larger funds, it is difficult or impossible to perform a meaningful valuation of all of the private companies in the portfolio on a yearly basis (indeed, the Crocus board was assisted by an external valuation expert). In addition, nominally independent valuators will no doubt be concerned to earn a repeat engagement the following year. Their tendency will thus be to err on the side of conservatism in proposing downward revisions, while adopting a more enthusiastic posture in relation to upward revisions. Without any market transaction to supply a truly independent benchmark as to value, the requirement for an independent valuation is thus a far from bulletproof protection for investors.

LSVCCs sell shares to investors on the basis of net asset value, as derived from the balance sheet. If the balance sheet figure is overstated, new investors will purchase their shares at an overvalue. Because new cash flows in at an unrealistically high valuation, this effects a subsidization of old investors by new investors.

74 See the Settlement Agreement between the Manitoba Securities Commission and the former directors of Crocus, available at http://www.msc.gov.mb.ca/legal_docs/orders/6414_crocus.pdf, in addition to the staff allegations pertaining to the proceedings before the commission: In The Matter of: the Crocus Investment Fund: Statement of Allegations of Staff of the Manitoba Securities Commission, available at http://www.msc.gov.mb.ca/legal_docs/investigation/hearings/crocussoa.html. The fund's auditor made no adverse comment on the fund's valuation practices.

75 See http://www.msc.gov.mb.ca/media_events/events_releases/crocus.html; http://www.msc.gov.mb.ca/legal_docs/investigation/hearings/crocussoa.html; http://www.msc.gov.mb.ca/legal_docs/orders/6414_crocus.pdf.

76 National Instrument 81-106: Investment Fund Continuous Disclosure. Part 2.1 contains a baseline requirement that the annual financial statements of an investment fund contain a statement of net assets, a statement of changes in net assets, and a statement of investment portfolio as of the end of each financial year. Part 3.1.2 further requires that the statement of net assets disclose the current value of each of the fund's investments. Part 3.5(5) requires that the statement of investment portfolio disclose the current value of each portfolio asset. Part 8 applies exclusively to labour-sponsored funds. It exempts an LSVCC from disclosing the current value of each investment in its portfolio as long as it discloses (inter alia) the individual cost of each investment, the total current value of each investment, and the total adjustment from cost to current value for all venture investments, and provided that the fund "has obtained an independent valuation relating to the value of the venture investments or to the net asset value of the fund" (part 8.2(c)). The instrument further defines an independent valuation as "a valuation of the assets and liabilities, or of the venture investments, of a labour-sponsored or venture capital fund that contains the opinion of an independent valuator as to the current value of the assets and liabilities, or of the venture investments" (part 1.1). 


\section{PART IV: THE SCIENTIFIC RESEARCH AND EXPERIMENTAL DEVELOPMENTAL (SR\&ED) TAX CREDIT}

\section{The Jenkins Panel's Antipathy to the SR\&ED}

The SR\&ED tax credit is the single largest program directed at encouraging innovation, delivering about $\$ 3.5$ billion in benefits to something like 24,000 businesses annually. ${ }^{77}$ This constitutes more than half of all federal funds directed toward innovation. ${ }^{78}$

The SR\&ED has a refundable component, pursuant to which the government reimburses businesses undertaking innovative research for 20 percent of their qualifying expenditures, whether or not the firm has taxable income. If the firm is a Canadian-controlled private corporation (CCPC), the reimbursement rate is 35 percent on the first $\$ 3$ million of qualifying expenditures and 20 percent on the excess.

The Jenkins panel recommends that SR\&ED-eligible expenditures be restricted to labour costs only, eliminating reimbursement for non-labour expenses such as capital costs and overhead. ${ }^{79}$ While also recommending an offsetting increase in the reimbursement rate, the panel suggests that this rate gradually be reduced over time, with the savings transferred to programs delivering direct forms of assistance such as grants. The panel also suggests that these changes be restricted to CCPCs, with consideration given to eventually extending them to generally larger non-CCPCs.

Much of the panel's antipathy to the SR\&ED is based on Department of Finance research concluding that within five years of incorporation, only about two percent of all firms receiving SR\&ED money grow into large firms that continue to undertake R\&D. ${ }^{80}$ For this reason, the committee suggests that much of the government's SR\&ED largesse is directed at firms that are unlikely to succeed in the commercialization sweepstakes (i.e., the program has a low degree of target efficiency). There are a number of problems, however, with this reasoning.

\section{A Response to Jenkins}

\section{NO COMPARISON TO DIRECT ASSISTANCE FAILURE RATES}

The significance of the two percent figure cannot be evaluated without comparison to the growth rates of firms receiving direct assistance. No such comparison is offered.

\footnotetext{
77 Jenkins Report, p.3-3; p.6-5.

78 The Jenkins panel estimates that the total federal expenditure on innovation is $\$ 6.44$ billion. See Jenkins Report, p.33.

79 Jenkins Report, p.6-10.

80 Jenkins Report, p.6-12.
} 


\section{A COMPARISON TO SILICON VALLEY SURVIVAL AND GROWTH RATES}

The two percent in five years figure is derived from data in the $2000-2004$ period $^{81}$ - that is, the period immediately following the bursting of the high-tech bubble in March of 2000. It is well documented that high-tech failure rates are generally higher in post-bubble periods, ${ }^{82}$ and were in fact higher in the post-2000 period than in any other historical period. ${ }^{83}$ Thus, a pivotal datum underlying the committee's views regarding the SR\&ED is derived from unrepresentative data.

It is interesting and informative to compare the failure rates of firms born in Silicon Valley, the world's premiere high-tech incubator, over a similar period of time. ${ }^{84} \mathrm{~A}$ study by Luo and Mann indicates that more than two-thirds of the high-tech companies founded in Silicon Valley in 2000 (in which a record amount of venture capital money was poured into Silicon Valley businesses) were no longer in business by $2004 .{ }^{85}$ By 2009 , fewer than one in five were still in business. ${ }^{86}$ Few survivor firms grew substantially. In 2000, the 2,600 high-tech businesses founded in that year had aggregate employment of 27,000 workers. By 2009, that had shrunk to 9,400 for the entire cohort. ${ }^{87}$ Among the firms that survived to 2009 , average employment only doubled. ${ }^{88}$

Since firms receiving SR\&ED assistance are overwhelmingly small CCPCs, it is instructive to look at the growth and survival rates of comparable Silicon Valley firms founded in 2000. Only 17 percent of the small firms (those with four employees or fewer when founded) founded in 2000 survived to $2009,{ }^{89}$ despite "the mammoth amounts of venture capital investment in Silicon Valley during and around the year 2000." 90 On average, these survivor firms approximately doubled their employment. Thus, the average small firm that survived ended up as a medium-sized firm as defined in the study (5-49 employees). A similar percentage of firms that were medium-sized in 2000 survived to 2009. Of the survivors, average employment grew by 50 percent; thus, fewer than half of the initially medium-sized firms ended up as large firms as defined in the study (50 or more employees). Based on these figures, it would appear that no more than four percent of small and medium-sized Silicon Valley firms founded in 2000 went on to become large firms by 2009, or ten years after the commencement of the data period.

81 Jenkins Report, p.6-12: "Analysis by the Department of Finance of start-ups created over the 2000-2004 period indicates that, within five years following incorporation, approximately two percent of innovative start-ups grow into large firms that continue to undertake R\&D."

82 See e.g. Yuji Honjo, "Business failure of new firms: An empirical analysis using a multiplicative hazards model" (2000), 18 J. of Industrial Organization 557 (bubble failure rates generally higher for start-up firms).

83 See e.g. Tian Luo and Amar Mann, "Survival and Growth of Silicon Valley high-tech businesses born in 2000," Sept. 2011 Monthly Labor Review 16. Much of the inferior performance was due to two factors: poor macroeconomic performance in the 2000-2008 period (and in particular 2001-2003, and 2008), and the industry mix of firms funded in 2000. The firms examined in the Department of Finance study were subject to similar macroeconomic factors, although the industry mix of Canadian firms may well have been somewhat different (given the generally greater concentration of Silicon Valley firms in this period in information technology). The performance of the year 2000 cohort relative to the benchmark is overstated due to the fact that the record amounts of venture capital invested in 2000 were not taken into account in specifying the performance benchmark.

84 The Luo and Mann study is restricted to firms founded in 2000, while the Department of Finance study examines firms founded in 2000-2004. Nonetheless, the two studies are broadly comparable.

85 Luo and Mann, supra, note 83.

86 Ibid. at 18 .

87 Ibid. at 18.

88 Ibid. at 19.

89 Ibid. at 19.

90 Ibid. at 22. 
Thus, the extraordinary fact is that, of the high-tech firms created in the world's leading hightech incubator in 2000, many of which had generous venture backing, about the same percentage grew into large firms over 10 years as those firms receiving Canadian SR\&ED assistance over five years. This puts a rather different complexion on the two percent in five years figure relied upon by the Jenkins Committee as a central datum in its conclusion that the SR\&ED program has low target efficiency.

\section{SUCCESSFUL FIRMS MAY NEVER GROW INTO LARGE FIRMS}

\section{Firms that Licence Their Technology}

Firms engaged in successful R\&D may not grow into larger firms within five years - or indeed ever. Rather, they may choose to become coupon clippers and license their technology to larger market actors. Firms that engage in this strategy will never grow into large firms, even though they may generate significant technological advances and considerable profits for their owners.

In fact, it is commonplace for university technology transfer departments to encourage university researchers to licence their technology, rather than take the much bigger gamble of building the enterprise into a manufacturing company.

\section{Firms Bought Out in an M\&A Transaction}

Most successful entrepreneurs and early-stage investors will ultimately seek to monetize their investments via either an initial public offering or a sale of the entire firm to a third party typically a much larger strategic acquirer that seeks to meld the target's technology with its own. ${ }^{91}$ Evidence compiled by the CVCA indicates in the past several years M\&A exits (or sales of the entire firm to a third party) have been the dominant form of exit taken by Canadian venture capital-backed companies. Between 2003 and 2010, there were 47 exits of VC-backed companies via initial public offerings, versus $248 \mathrm{M} \& \mathrm{~A}$ exits. ${ }^{92}$

By definition, when a small firm sells out to an acquirer, it will never grow into a large firm. Despite this, the data indicates that the average M\&A exit is very profitable for entrepreneurs and early-stage investors (and possibly the most profitable form of exit for Canadian companies)..$^{93}$ Thus, the fact that only two percent of SR\&ED recipients grow into large companies within five years of incorporation does not seem to tell us very much about whether the SR\&ED money was well spent.

\footnotetext{
91 Cumming and MacIntosh, supra, note 12; Ronald J. Gilson and Bernard S. Black, "Venture Capital and the Structure of Capital Markets: Banks Versus Stock Markets” (1998), 47 J. Fin. Econ. 243.

92 See “Canada's Venture Capital Industry in 2009," Thomson Reuters, p.33, available at http://www.cvca.ca/files/Downloads/Final_English_Q4_2009_VC_Data_Deck.pdf, and "Canada's Venture Capital Market in 2010," Thomson Reuters, p. 32, available at http://www.cvca.ca/files/Downloads/Final_Q4_2010_VC_Data_Deck_English.pdf.

93 Cumming and MacIntosh, supra, note 12.
} 


\section{THE FIVE-YEAR TIME HORIZON IS TOO SHORT}

Venture capitalists typically anticipate an investment horizon of three to eight years before they exit their investments - the shorter end of the spectrum generally being reserved for laterstage investments. ${ }^{94}$ Since VCs will tend to invest several years after start-up, this means that (aside from software developers, for which product development times are relatively short) many high-value technological breakthroughs spend 10 or more years in the lab before hitting it big, even with venture capital backing. RIM (a venture-backed company), often seen as one of Canada's great innovation successes, took longer. Though founded in 1984, it was not until 1999 that RIM hit pay dirt with the introduction of the BlackBerry. E-Ink, which developed the technology underlying most e-readers, began its commercialization journey in 1995, but the first e-readers did not hit the shelves until 2005, a full 10 years later (and with the benefit of some $\$ 140$ million of venture capital funding). Using the panel's metric, both RIM and E-Ink would have been judged to be failures undeserving of government funding.

\section{THE SR\&ED AS A BRIDGE ACROSS THE VALLEY OF DEATH}

In 2007 (the last year in which there is complete data), 20,000 CCPCs received SR\&ED payments averaging $\$ 65,000$ per firm. ${ }^{95}$ This implies average SR\&ED-eligible expenditures of about $\$ 185,000$ per firm. The aggregate SR\&ED payment to these 20,000 firms was $\$ 1.3$ billion $^{96}-$ not very far off the estimated size of Canada's annual angel investment. However, much of that angel money flows to non-high-tech businesses. ${ }^{97}$ Thus, it seems very likely that a large portion of the 20,000 CCPCs receiving SR\&ED monies were mostly or entirely funded by the firm's entrepreneur, family and friends. Some would have received angel investment too, but very few would have received funds from venture capitalists or strategic partners, which (as the Jenkins Report recognizes ${ }^{98}$ ) generally come in quite a bit further down the road. Few, if any, would have received funding from mezzanine lenders or merchant banks. By definition, no CCPC would have tapped into the public capital markets. All of this implies that the bulk of firms receiving SR\&ED money are very early-stage firms developing speculative technologies that would normally be expected to have high failure rates.

This might be taken as confirmation of the Jenkins Committee's view that, because the SR\&ED has low target efficiency, it should be scaled back in favour of direct assistance. Such a conclusion should be staunchly resisted, for two reasons. One is that these firms are the acorns from which mighty oaks grow. The analogy is particularly apt insofar as very few acorns grow into mighty oaks, just as very few small CCPCs will develop game-changing technologies and/or grow into industrial giants. However, if all of the acorns are scoured from the forest floor, we can be quite confident that we will get no mighty oaks at all.

\footnotetext{
94 Cumming and MacIntosh, supra, note 12.

95 Jenkins Report, p.6-5.

96 Ibid.

97 See e.g. Equinox Management Consultants Ltd., Informal Equity Capital for SMEs: A Review of Literature, prepared for Industry Canada, March, 2000.

98 See Jenkins, Figure 7.1, p. 7-12.
} 
That these firms have a low probability of success is fully consistent with the view that many are engaged in cutting-edge research. Indeed, virtually by definition, firms operating at the cutting-edge will have a low probability of success. If they did not, they could not be said to be at the cutting-edge (or the bleeding edge, as it is sometimes called). Without cutting-edge research, where are the commercializable technologies to come from?

The second reason why the SR\&ED should not be scaled back because of high failure rates is that, aside from money from friends, family, and an irregular assortment of angels, SR\&ED money is likely to be the only money available to small CCPCs. Such firms are often said to inhabit the Valley of Death, a gap in funding that exists between public funding of early-stage pre-commercial research, and later-stage private funding furnished by venture capitalists, strategic partners, mezzanine lenders, merchant bankers, and public capital markets. As explained by Murphy and Edwards: ${ }^{99}$

....the availability of public sector funds decreases abruptly after the technology is created because the public sector views subsequent investment as the purview of the private sector. This drop-off of public investment occurs at the same time that the investment needs of the venture are actually growing. Hence, the entrepreneurial venture must often turn to equity financing for at least part of the resources needed. Further, adequate levels of angel and seed investor resources are often not available as a precursor to venture capital, especially for high technology. This is why we call the region between the technology creation stage and the early commercialization stage the cash flow valley of death.

The existence of the Valley of Death is an artefact of high information asymmetries. That is, it is very difficult for potential outside funders to evaluate the firms' technology, management team, and market opportunities. That is precisely why venture capitalists and other private investors tend to shy away from seed-stage investments, and hence why the Valley of Death exists.

Increased direct funding to early stage firms is not the answer. If highly skilled private investors cannot pick winners and losers, can we truly expect government bureaucrats to do so? If the goal is to enhance target efficiency, transferring funds from the SR\&ED to direct funding is not likely to accomplish this goal.

In summary, the SR\&ED credit, at least insofar as it provides assistance to smaller firms, should be left untouched. Such firms are an indispensable part of the innovation ecosystem. In the absence of private funding or effectively targeted public funding, we must be prepared to offer a high degree of leverage to early stage money via the SR\&ED program - even in the knowledge that much of this research will ultimately fail to produce a commercializable product or service.

99 Lawrence Murphy and Peter Edwards, "Bridging the Valley of Death," Innovation: America's Journal of Technology Commercialization, 2(3), June/July 2004, available at http://www.innovation-america.org/bridging-valley-death. 


\section{INTRINSIC MARKET DISCIPLINE}

While the panel evinces concern that SR\&ED is not well targeted, it is important to point out that SR\&ED has a built-in market discipline. In order to claim the SR\&ED, someone has to invest the other 65 percent of the funds ( 80 percent for firms that are not Canadian-controlled private corporations). That money will be lost if the research bears no fruit. That supplies a potent incentive to make sure that the research has a decent chance of succeeding. Indeed, the tax credit portion of the SR\&ED is only available to firms that have taxable income. These firms have the best form of market certification possible - customers.

\section{BUREAUCRATIC SIMPLICITY, FAVOURABLE TIMELINES, AND RELATIVELY MODEST OPPORTUNITY COST}

In addition, since SR\&ED does not require a bureaucratic assessment of merits, the risk of applying is far less. This is a far from trivial advantage. For a human-capital-constrained startup, the opportunity cost of applying for funds can be very significant, as critical employees are pulled away from the research and cast into the sometimes bottomless pit of filling out forms and engaging with grant personnel. The prospect of expending material time and effort, with nothing to show for it, can act as a significant deterrent to applying.

The SR\&ED is also much faster than most direct assistance programs. While SR\&ED credits are typically processed in four to six months, ${ }^{100}$ it is not unusual for successful applicants in granting competitions to wait a year or more before receiving a cheque. As Elon Musk (Paypal's co-founder) has stated, starting a company is like staring into the face of death. ${ }^{101}$ For high-tech start-ups, a year is more like a century.

\section{RESTRICTING SR\&ED TO LABOUR COSTS UNLIKELY TO MATERIALLY REDUCE APPLICATION COSTS}

The motivation for restricting SR\&ED to labour costs is to reduce the complexity of applying for the SR\&ED, which, according to the panel, "leads to increased reliance on third-party consultants to prepare R\&D claims."102 The panel's survey results suggest that these costs average 14 percent of the value of credits for small firms, and five percent for large firms.

It seems unlikely, however, that restricting SR\&ED-eligible expenditures to labour costs will substantially reduce the burden of applying for the SR\&ED, nor reliance on third-party experts such as accountancy firms. Computation of non-labour costs is only one of many reasons why SR\&ED applications can be time-consuming and expensive. The revenuers must be satisfied that the work in question aims at improving a product or process via an experimental approach, and that there is technological uncertainty. A myriad of documents is required. On both counts, the involvement of an experienced hand greases the wheel - someone who knows from experience how to draw up a satisfactory project report, what questions are likely to arise, and how to go about answering them. Reducing the eligibility base to labour costs is unlikely to make it more practical for entrepreneurs to apply on their own.

\footnotetext{
${ }^{100}$ Jenkins Report, p.6-6, supplemented by conversations with SR\&ED recipients.

${ }^{101}$ http://techcrunch.com/2011/09/14/elon-musk-starting-a-company-is-like-staring-into-the-face-ofdeath/?utm_source=pulsenews\&utm_medium=referral\&utm_campaign=Feed\%3A+Techcrunch+\%28TechCrunch $\% 29$.

102 Jenkins Report, p.6-11.
} 
Nor would the diminished application cost make anything like a sea change in the quantum of net proceeds flowing to SR\&ED-eligible firms. If the Jenkins Report is correct in asserting that applying for the SR\&ED costs the average CCPC 14 percent of its SR\&ED proceeds, and the average larger firm five percent, the total costs of applying are on the order of $\$ 300$ million. $^{103}$ What is up for grabs is not the entire cost of applying, but the marginal cost reduction that would result from restricting eligibility to labour costs. Supposing that this change results in a 25 percent reduction in application cost, that would reduce aggregate application cost by $\$ 75$ million. That is a scant two percent of aggregate SR\&ED funding. This modest figure scarcely seems to compel the conclusion that a major change in the eligibility base is warranted.

\section{TILTING THE PLAYING FIELD IN FAVOUR OF FIRMS WITH HIGH LABOUR/CAPITAL RATIOS AND LARGER FIRMS}

Reducing the SR\&ED to labour costs (coupled with increasing the reimbursement rate) would significantly tilt the playing field in favour of industries with high labour to capital ratios (such as software development) and against others with low labour to capital ratios (just about everything else). This tilt cannot be justified from any defensible policy perspective. Nor will it sit well with provinces - and in particular Ontario and Québec - where a great deal of capital-intensive $\mathrm{R} \& \mathrm{D}$ takes place, making it a political hot potato.

As the Jenkins Panel would confine the change in eligible expenses to CCPCs, there would also be a tilt in the playing field in favour of large firms, at the expense of smaller upstarts. This will have the effect of entrenching larger firms in their particular market niches, reducing competition, and almost certainly reducing the rate of innovation.

\section{DIFFERENCES IN SECTORAL WEIGHTINGS BETWEEN DIRECT AND INDIRECT SUPPORT}

The Jenkins Report helpfully summarizes the distribution of both direct and SR\&ED assistance by industrial sector. ${ }^{104}$ There are material differences in the two forms of assistance. For example, 9.8 percent of all direct assistance in 2010-2011was paid to Agriculture, Forestry, Fishing and Hunting, while only 1.4 percent of the SR\&ED credits paid in 2007 (the last year in which there is complete data) went to this sector. The comparative figures for Oil and Gas Mining are 3.8 percent (direct) and 8.7 percent (SR\&ED). For Professional, Scientific and Technical Services, they are 11.6 percent (direct) versus 23.6 percent (SR\&ED). Overall, Goods Industries received 71.7 percent of direct funding, but only 55.8 percent of SR\&ED funding. Service Industries received 27 percent of direct funding, but 44 percent of SR\&ED funding.

Without making any evaluation of the relative merits of these different weightings, the simple point is that if funds are transferred from the SR\&ED to direct funding, this will have a material impact on the sectoral distribution of government largesse (and will do so even if no changes are made in SR\&ED-eligible expenses and/or reimbursement rates). There will be winners and losers. Without exploring the reasons for these differences in sectoral allocations and their policy rationales, it is impossible to say whether this would be a good thing, a bad thing, or some mixture of the two. However, prior to acting on the Jenkins recommendations, it

\footnotetext{
103 This is based on figures provided in the Jenkins Report, p.6-8.

104 Jenkins Report, Figure 3.5, at p. 3-13.
} 
would be prudent for the government to undertake such an analysis. It would also be prudent for the government to prepare for the vigorous protests that are likely to issue from those sectors whose oxes are gored by re-allocating money from SR\&ED to direct assistance.

\section{REGIONAL AND SECTORAL BIAS IN DIRECT FUNDING}

The SR\&ED credit applies agnostically across all firms regardless of size or industrial sector, while granting programs are often directed at particular industrial silos. The desirability of the broader approach is specifically endorsed by the committee, which states that "firms and entrepreneurs [should be empowered] to make market-driven investment decisions according to their own timelines and regardless of sector, technology or region." ${ }^{105}$ This approach is reflected in the operating principles for the committee's proposed Industrial Research and Innovation Council (IRIC), an overlord agency that would oversee all federal assistance for innovation. ${ }^{106}$ It is also reflected in the committee's strongly held view that regional funding programs should require applicants to meet precisely the same funding requirements as national programs. ${ }^{107}$

While endorsing an industry-, technology- and region-agnostic approach to funding, the Jenkins Committee overlooks the fact that direct funding lends itself much more readily to political interference. The OECD views this distinction as of central importance in defining direct versus indirect assistance:

In practical terms, the main distinction between direct and indirect support is that the latter is open ended and is available to all firms, whereas the former is limited in overall funding and is allocated by program administrators to specific projects, industries or regions. Direct support can therefore be targeted to specific areas, contrary to more neutral indirect measures. ${ }^{108}$

The Jenkins Panel estimates that 14 percent of direct expenditure in support of business innovation is regionally oriented. ${ }^{109}$ By population, this spending is far from even-handed. The Maritimes, for example, with 6.8 percent of the Canadian population, ${ }^{110}$ receives 8.4 percent of all federal direct spending (including NRC institutes located in the Maritimes). ${ }^{111}$

${ }^{105}$ In full, the Jenkins Report states:

The Panel believes that the foundational core of the federal suite of business innovation programs should be large national programs of broad application - for example, the SR\&ED program and Industrial Research Assistance Program (IRAP) - that support business innovation activity generally, empowering firms and entrepreneurs to make market-driven investment decisions according to their own timelines and regardless of sector, technology or region.” Jenkins Report, p.4-2.

${ }^{106}$ Jenkins Report, p.5-11.

107 Jenkins Report, p.4-2.

108 Organisation for Economic Co-operation and Development, "Measuring Innovation: A New Perspective" (Paris: OECD, 2010), cited in the Jenkins Report, p.6-3.

${ }^{109}$ This includes the Atlantic Innovation Fund (4.4 percent), the Western Diversification Program (4.9 percent), the Business and Regional Growth Program (Québec) (3.4 percent), the Northern Ontario Development Program (0.3 percent), and the Applied Research and Commercialization Initiative (0.1 percent). Jenkins Report, p.3-4.

${ }^{110}$ Statistics Canada, http://www40.statcan.gc.ca/101/cst01/demo02a-eng.htm.

${ }^{111}$ The Atlantic Innovation Fund (4.4 percent), the Business Development Program ( 0.9 percent), Institute for Marine Biosciences (NRC) (1.1 percent), Institute for Ocean Technology (0.7 percent), Institute for Information Technology (1.3 percent). 
The BDC, which is the primary target of the Jenkins Committee's plan for enhanced direct assistance, exhibits a strong regional bias in favour of Québec and the Maritimes. With only 23 percent of the Canadian population, Québec receives 32.5 percent of all BDC loans and an astonishing 49.2 percent of all BDC subordinate financing investments. With 6.8 percent of the Canadian population, the Maritimes receives 10.7 percent of all BDC loans and $10.2 \%$ percent of all subordinate financing investments.

By contrast, with 38 percent of the Canadian population, Ontario receives only 30.1 percent of all BDC loans ${ }^{112}$ and 24.5 percent of subordinate financing investments. ${ }^{113}$ The four western provinces (BC, Alberta, Saskatchewan, and Manitoba) are also underrepresented. While accounting for 30.9 percent of Canada's population, they receive only 25.5 percent of BDC loans and 15.8 percent of all subordinate financing investments. ${ }^{114}$

It is difficult not to believe that political agendas drive these figures, and that the BDC and other nominally national programs have been, and continue to be, used as tools of political favouritism to confer benefits on some regions of the country at the expense of others. If the Jenkins Report's recommendation to strip money from the SR\&ED credit and give it to BDC is implemented, it will only strengthen the regional bias of federal direct funding.

It is also likely to strengthen the sectoral bias of federal funding. Over 20 percent of federal largesse is directed at a mere three industries: aerospace (10.1 percent) ${ }^{.15}$ forest products $(5.7$ percent) ${ }^{.16}$ and agriculture (5 percent). ${ }^{117}$ In addition, various sector-oriented NRC institutes collectively account for 18.4 percent of all federal direct spending.

Thus, while recognizing the virtues of an industry-, region-, and technology-agnostic approach to funding, the Jenkins Committee's primary recommendations are likely to cause federal funding to depart more strongly from this objective.

\footnotetext{
112 BDC Annual Report 2011, p.78.

113 Ibid. p.79.

${ }^{114}$ Ibid. p.79. In addition, as documented earlier, the Québec-based LSVCC funds, with many billions of dollars under administration, exist for purposes unrelated to fostering innovation. These programs are driven primarily by regional development and union employment, and have received billions of dollars in federal support.

${ }^{115}$ The Strategic Aerospace and Defence Initiative (7.6 percent), Space Technology Development Program (0.5 percent), Institute for Aerospace Research (NRC) (2.0 percent).

${ }^{116}$ FPInnovations (5.2 percent), FPInnovations - Canadian Wood Fibre Centre (0.5 percent).

${ }^{117}$ Agricultural Bioproducts Innovation Program (1.1 percent), Canadian Agri-Science Clusters (0.8 percent), Developing Innovative Agri-Products (0.4 percent), Agricultural Bioproducts Innovation Program (1.0 percent); Canadian Agri-Science Clusters (0.4 percent), Developing Innovative Agri-Products ( 0.4 percent), Plant Biotechnology Institute (NRC) (0.9 percent).
} 


\section{Three Alternatives to Jenkins}

\section{REDIRECT SECTOR-FOCUSED FUNDING TO ADVANCED MANUFACTURING}

If federal funding is to be sector-oriented, this orientation should, above all, be directed toward advanced manufacturing. The President's Council of Advisors on Science and Technology (PCAST) defines advanced manufacturing as:

a family of activities that (a) depend on the use and coordination of information, automation, computation, software, sensing, and networking, and/or (b) make use of cutting-edge materials and emerging capabilities enabled by the physical and biological sciences, for example nanotechnology, chemistry, and biology. This involves both new ways to manufacture existing products, and especially the manufacture of new products emerging from new advanced technologies. We believe that advanced manufacturing provides the path forward to revitalizing U.S. leadership in manufacturing, and will best support economic productivity and ongoing knowledge production and innovation in the Nation.

Economists have only recently come to understand that advanced manufacturing is an integral part of a well-functioning innovation ecosystem. It has become an article of faith to think that while the process of innovation is central to the future of western economies, manufacturing can (and should) be effected in cheaper offshore locales. Pisano and Shih argue that this conventional wisdom is sometimes correct, but just as often wrong. For one thing, when manufacturing is exported, so are high-tech jobs, depriving the local economy of the ability to innovate. For another, co-location of manufacturing and R\&D may be an essential ingredient in the innovation process. ${ }^{118}$ This is likely to be the case, they argue, if product design and production processes are difficult to modularize or disentangle. It is also likely to be the case where production techniques are immature and hence in a state of rapid flux, so that product and process are difficult to separate. Consequently, "an explicit focus on manufacturing is essential to innovation policy - especially since the exodus of any manufacturing that's tightly linked to product design is certain to pull R\&D abroad as well." 119

It is important to recognize that outsourcing does not necessarily involve going offshore; firms may outsource to domestic producers as well. This is an important intermediate option. Building a manufacturing facility can be both time-consuming and expensive, and will usually require a major new round of funding. Particularly if the manufacturing process is complicated, it will take time and a great deal of managerial effort, in an area outside of the firm's core

${ }^{118}$ Gary P. Pisano and Willy C. Shih, "Does America Really Need Manufacturing?" (2012), 90 Harvard Business Review 94. See also Gary P. Pisano and Willy C. Shih. "Restoring American Competitiveness" (2009), 87 Harvard Business Review 114; Erica R.H. Fuchs and Randolph Kirchain, "Design for Location: The Impact of Manufacturing Offshore on Technology Competitiveness in the Optoelectronics Industry," 56(12) Management Science 2323; David Rotman, “Can We Build Tomorrow's Breakthroughs?” MIT Technology Review, January/February 2012.

${ }^{119}$ Pisano and Shih, "Does America Really Need Manufacturing?" ibid. 
expertise, to replicate the expertise of market incumbents. ${ }^{120}$ Building manufacturing facilities can also greatly enhance the firm's systematic risk by increasing its financial and/or operating leverage. In can also expose the firm to an added technological risk - i.e., the danger that its manufacturing facilities will be rendered obsolete by process innovations introduced by competitors. Thus, many start-up firms will choose to outsource their production work.

But while both domestic and offshore outsourcing avoid the above-mentioned perils, only domestic outsourcing allows the firm to retain some measure of geographic proximity to its production facilities, and hence some ability to exploit research/production synergies. In short, the existence of a multi-dimensional high-tech manufacturing sector is an important ingredient in fostering innovation by technology start-ups.

It is also an important consideration for governments that invest heavily in promoting innovation. If the absence of domestic production options causes recipients of government support to relocate outside the country, the benefits of this subsidization accrue primarily to foreigners.

The importance of a domestic advanced manufacturing sector inspired the President's Council of Advisors on Science and Technology to recommend the adoption of a $\$ 500$ million funding facility to be set aside for an "advanced manufacturing initiative." 221 The importance of advanced manufacturing has also been recognized by European governments, at least three of which have, for example, funded the establishment of domestic biomanufacturing facilities in order to protect their earlier investments in biotech start-ups. ${ }^{122}$

How does this fit into the direct versus indirect debate? The Jenkins Report indicates that 52.7 percent of all direct assistance goes to manufacturing, compared to 44.5 percent of SR\&ED money. Thus, one might initially presume that direct funding is more likely to achieve the goal of supporting advanced manufacturing. However, there is no reason to believe that this is the case. SR\&ED funding is directed in a relatively focused fashion at the kind of innovation that is characteristic of advanced manufacturing, since qualifiers must demonstrate that they aim at improving a product or process via an experimental approach. By contrast, as noted above, direct assistance programs are heavily influenced by regional funding objectives.

A material proportion of direct assistance is also sectorally oriented in areas that cannot be styled advanced manufacturing. While a good many of the NRC institutes appear to operate in the advanced manufacturing space, ${ }^{123}$ a large portion of other direct assistance does not, including the 20 percent of total direct assistance flowing to aerospace, forestry and agriculture. These, and other sectoral allocations to industries such as fishing and hunting, construction, and utilities, are all disproportionately supported by direct assistance.

\footnotetext{
${ }^{120}$ This expertise extends not only to the production process, but to the sourcing of raw materials, the location and preferences of customers, distribution channels, potential strategic relationships, marketing techniques, knowledge of the competitive landscape, and many other factors.

121 "Report to the President on Ensuring American Leadership in Advanced Manufacturing," Executive Office of the President, President's Council of Advisors in Science and Technology, June 2011, available at http://www.whitehouse.gov/sites/default/files/microsites/ostp/pcast-advanced-manufacturing-june2011.pdf.

${ }^{122}$ Peter Vermij, "Governments backing manufacturing to save start-ups," Bioentrepreneur 28 April 2005, available at http://www.nature.com/bioent/2005/050401/full/bioent860.html.

${ }^{123}$ For example, the Biotechnology Research Institute, the Institute for Microstructural Sciences, the Institute for Biological Sciences, the National Institute for Nanotechnology, the Steacie Institute for Molecular Sciences, and the Institute for Chemical Process and Environmental Technology.
} 
In addition, many federal and provincial programs that deliver direct funding are concentrated in funding silos such as those dedicated to green or renewable energy companies. As the President's Council's definition of advanced manufacturing makes clear, however, advanced manufacturing is concentrated in industry-agnostic platform technologies. A good example is nanotechnology - the science of manipulating matter at the molecular or atomic scale. ${ }^{124}$ Nanotechnology is capable of fundamentally altering the basic properties of both familiar and exotic materials, producing new classes of materials with a virtually infinite range of uses. As a platform technology, it is widely expected that nanotechnology will have applications in everything from medicine to industrial processes to consumer goods as widely divergent as personal computers and tennis balls. ${ }^{125}$ However, at present, nanotechnologies that cannot fortuitously be squeezed into a funding silo tend to fall through the cracks.

It is imperative that the federal and provincial governments focus on advanced manufacturing as a fundamental determinant of government assistance - be it direct or indirect. Pending a detailed examination of the relative merits of direct and indirect assistance in supporting advanced manufacturing, however, it is probably safe to assume that the SR\&ED program is more likely to advance the cause of advanced manufacturing than are direct assistance programs.

\section{BASE DIRECT ASSISTANCE FLOWING TO EXPERIMENTAL DEVELOPMENT PRIMARILY ON THE SR\&ED CREDIT AND ANGEL SIDECAR FUNDS}

The Jenkins Committee classifies federal direct funding programs along the lines suggested by the OECD's Frascati Manual. ${ }^{126}$ These are basic research, applied research, experimental development, and commercialization. Basic research, by definition, involves no commercialization objective. Applied research "is also original investigation undertaken to acquire new knowledge," 127 but "is directed primarily towards a specific aim or objective." 128 It might thus be thought of as pre-commercial research; that is, research that might ultimately generate a possible commercial application. Experimental development, by contrast, typically has a specific commercialization objective in mind.

The report observes that "the great majority of $R \& D$ performed by business is for experimental Development", ${ }^{129}$ and that "allocation of the SR\&ED tax credit, averaged over 2000-07, is

\footnotetext{
${ }^{124}$ A nanometer is a billionth of a meter.

${ }^{125}$ See generally the Project on Emerging Nanotechnologies, which identifies nanotechnology inventions currently in use as well as those that we might expect to see in the future; http://www.nanotechproject.org/index.php?id=18.

${ }^{126}$ Jenkins Report, p.2-5. The panel adopts the following definition from the Frascati Manual: Proposed Standard Practice for Surveys on Research and Experimental Development (Paris: OECD, 2002), p.30:

Basic research is experimental or theoretical work undertaken primarily to acquire new knowledge of the underlying foundation of knowledge and observable facts, without any particular application to its use in view. Applied research is also original investigation undertaken in order to acquire new knowledge. It is, however, directed primarily towards a specific aim or objective. Experimental is systematic work, drawing on existing knowledge gained from research and/or practical experience, which is directed to producing new materials, products or devices, to installing new processes, systems or services, or to improving substantially those already produced or installed.

${ }^{127}$ Frascati Manual, ibid.

${ }^{128} \mathrm{Ibid}$.

${ }^{129}$ Jenkins Report, p 3-11 (citing Statistics Canada, Science Statistics: Industrial Research and Development, 2005 to 2009. Cat. no. 88-001-X (Ottawa, Statistics Canada, 2009)).
} 
estimated to be mostly in support of experimental development." ${ }^{\text {"30 }}$ However, direct assistance spans all research categories, as follows (based on figures from 2010-11): basic research \$195 million; applied research $-\$ 516$ million; experimental development $-\$ 573$ million; and commercialization - $\$ 162$ million. ${ }^{131}$ From these figures, it can be seen that there is a substantial overlap between the SR\&ED and direct assistance: approximately 45 percent of the direct funding that is allocated to research goes to experimental development.

Basic and applied research, as well as experimental development, are all important parts of the innovation ecosystem. While basic research neither aims at, nor will typically result in a specific commercializable application, it is nonetheless a forerunner and necessary complement to applied research and experimental development. Because the private sector will not typically have a presence in either basic or applied research, the government has a special and irreplaceable role in funding both. The modus operandi for funding in these domains should be (as is presently the case) academic peer review. Academic peer review provides a solid decision-making foundation that maximizes target efficiency by giving the decision-making lead to highly knowledgeable experts in the field.

The domain of experimental development is quite different. Those engaged in experimental development are focused quite specifically on developing a commercializable application from a particular technology. The decision of how best to allocate government funds necessarily transcends mere science. It depends as well on a keen knowledge of the many and varied factors that play a role in assessing commercial potential, such as cost and revenue information, the competitive landscape, market structure, consumer demand, potential strategic partners, possible sources of funding, marketing strategies, distribution channels, product life cycles, exposure to systemic risk, and so on. For this reason, market-based assessments of potential are certain to be more reliable than those made by governments.

This is true even where governments draw upon outside business expertise to inform their views. Outside experts are fixed claimants. That is, they earn a flat fee that is independent of the success of the enterprise whose merits they are called upon to evaluate. Market players, on the other hand, are residual claimants. ${ }^{132}$ If the firm is a success, they potentially stand to make a great deal of money. This provides a much more potent incentive to make the right decision.

The difficulty with research in the experimental development phase, however, is that private players are notable principally for their absence. While a smattering of angel investors play in this domain, venture capitalists and strategic partners are usually absent (not to mention mezzanine lenders, merchant bankers, and public capital markets). Thus, indirect funding such as that supplied by the SR\&ED credit is likely to be the optimal form of government assistance.

\footnotetext{
${ }^{130}$ Jenkins Report, ibid.

${ }^{131}$ Jenkins Report, p.5-15.

${ }^{132}$ Early stage investments are virtually always made by way of residual claims such as equity or instruments convertible into equity, rather than by straight debt (i.e., a fixed claim).
} 
Where direct funding is used, I concur with the Jenkins Committee's view that the government should rely principally on private decision-makers. While the committee is somewhat short on specifics, they advocate the use of a sidecar fund with angel investors. There is already precedent for such funding; the federal government's FedDev program for example, leverages angel money through angels operating out of networks in southern Ontario. ${ }^{133}$

My proposal, however, is more sweeping than that of the Jenkins Committee. With savings appropriated from the SR\&ED, the Jenkins Report recommends that the government "direct the Business Development Bank of Canada (BDC) to allocate a larger proportion of its portfolio to start-up stage financing, preferably in the form of a "sidecar" fund with angel investor groups." ${ }^{34}$ Because of its heavily regional orientation, I would not recommend that the BDC be the vehicle for effecting this goal. However, I would go further than the Committee insofar as I would recommend that the government re-examine all of the $\$ 573$ million in direct funding currently spent on experimental development with a view to redirecting a material portion to angel sidecar funds and/or the SR\&ED credit.

Given the relatively undeveloped state of Canada's angel market, it would be unwise to rely exclusively, or even principally on leveraging angel investments in experimental development. The SR\&ED credit should play the principal role.

\section{RESTRICT THE SR\&ED TO SMALL FIRMS}

In 2007 (the last year with complete data) about \$1.3 billion in SR\&ED credits was paid to CCPCs, while $\$ 1.8$ billion was paid to "large firms." ${ }^{335}$ The average payment to a large firm was $\$ 700,000,{ }^{136}$ implying average SR\&ED-eligible expenditures of somewhere on the order of $\$ 3$ million. Restricting SR\&ED credits to CCPCs will immediately reduce the SR\&ED budget by about 60 percent - which is likely to result in far more substantial savings than implementation of the Jenkins Panel's recommendations. Restricting or eliminating the SR\&ED credit for large firms is thus an alternative means of financing an injection of money into direct funding programs (if this is thought desirable), while hewing to the Panel's revenueneutral mandate.

Whether or not this would be a good idea on policy grounds cannot be determined without an explicit evaluation of the relative costs and benefits of SR\&ED funding for large firms compared to small - in addition to an evaluation of the relative costs and benefits of direct funding. However, it is noteworthy that large firms are on an entirely different part of the economic spectrum from startups. Many will not only have customers and revenues, but taxable profits. They will long since have crossed the Valley of Death and have a wide array of available funding options, including venture capitalists, mezzanine lenders, merchant bankers, and public capital markets. By contrast, as noted earlier, CCPCs typically have a limited array

\footnotetext{
${ }^{133}$ See http://www.feddevontario.gc.ca/eic/site/723.nsf/eng/home/.

${ }^{134}$ Jenkins Report, p.7-17.

135 Jenkins Report, Figure 6.3, p.6-7. The report does not define "large firm," but it includes both large CCPCs and nonCCPCs. See Jenkins, p. 3-10.

${ }^{136} \mathrm{Ibid}$
} 
of funding options; those situated in the Valley of Death may have none at all. If government funding exists (at least in part) to correct market imperfections, these imperfections are much more likely to exist in respect of small CCPCs than their larger counterparts. This makes a prima facie case for preferring SR\&ED funding for small, as opposed to large firms.

\section{PART V: DIRECT VERSUS INDIRECT SUBSIDIZATION OF INNOVATIVE BUSINESS}

\section{What are Direct and Indirect Forms of Assistance?}

The Jenkins panel adopts the OECD distinction between direct and indirect funding, as follows:

The OECD (2010a, p. 76) defines direct and indirect funding as follows: "Government direct R\&D funding includes grants, loans and procurement. Government indirect $R \& D$ funding includes tax incentives such as $R \& D$ tax credits." In practical terms, the main distinction between direct and indirect support is that the latter is open-ended and is available to all firms, whereas the former is limited in overall funding and is allocated by program administrators to specific projects, industries or regions. Direct support can therefore be targeted to specific areas, contrary to more neutral indirect measures. ${ }^{137}$

In fact, direct programs come in many flavours. Appendix A indicates some - but by no means all - of the pertinent variables, which can be combined into virtually limitless permutations and combinations. Existing direct assistance programs differ not only in their form of assistance and delivery mechanism, but in respect of who decides who will receive funding, industry preference, regional preference, stage preference, grant size, target strategy, and the identity of eligible recipients. Perhaps most importantly, they often differ in their overarching goals.

\section{The Varying Design Challenges of Different Types of Direct Assistance}

Each of the variations in Appendix A presents policy makers with unique design challenges, and these challenges arise both in relation to means and ends. For example, as noted above, programs that aim at providing direct assistance to firms engaged in experimental design, with the avowed purpose of enhancing the likelihood of a successful commercialization, suffer from a high risk of selection error (i.e., choosing the wrong firms for funding). This suggests a particular means for accomplishing the stated purpose: reliance on private investors as the principal decision-makers. By contrast, programs that aim to increase employment or train skilled workers lend themselves much more easily to in-house decision-making by bureaucrats.

${ }^{137}$ Jenkins Report, p.6-3. 
The fact that every box in Appendix A is currently representative of one or more granting programs is the product of a multitude of factors, including policy, politics (e.g., lobbying by particular industry interest groups) and path dependency (i.e., an element of randomness deriving from how the winds of government and bureaucracy were blowing at the particular time the program was created). A full review of direct assistance programs should attempt to determine and evaluate these reasons. It should also, as the Jenkins Report suggests, seek to develop measures of relative performance, without which policy makers are essentially shooting in the dark in choosing how to deliver direct assistance.

In addition, it is unlikely that governments will ever choose a single overarching goal for their direct assistance programs. Rather, it is probable that all of the goals indicated in Appendix A (and very likely others) will continue to win political favour. This suggests that learned panels, academics, and government officials can perform a useful service by suggesting superior forms of organizational design to achieve each of the various goals that governments might choose to pursue.

\section{The Difficult Task of Picking Winners and Losers}

One of the chief difficulties with direct assistance is that we simply cannot have much confidence that government bureaucrats are well positioned to pick companies that are likely to succeed in the commercialization sweepstakes.

As illustrated in Appendices B and C, private investing by angels and venture capitalists is quite different in many respects from investment by governmental entities. ${ }^{138}$ Successful private investors have many years of experience working with high-tech start-ups. They specialize in particular slices of the technology spectrum, in order to leverage their expertise. The selection process is gruelling. Even after rigorously pre-screening prospects, they invest in no more than three out of every hundred that survive the initial screen; the pickiest, perhaps one out of every three hundred. ${ }^{139}$ In picking their investees, they not only draw on their extensive in-house expertise, but enlist the aid of high-powered academics or external consultants for a second opinion. By syndicating with other sophisticated angels or VCs, they pool their expertise and minimize the probability of errors.

Once invested, they monitor their investments very closely. On average, a skilled private VC manager will have only nine companies in his or her stable. He or she will be a director, will communicate with the investee company at least weekly, and will play a key role in plotting strategy. Even when the VC does not possess a majority of shares or nominate a majority of directors, it will reserve contractual powers of control that give it the right to select management, approve all major transactions, and to potentially veto any spending over a pre-set amount.

The VC or angel investor's skill set extends to locating customers, suppliers, strategic partners, distributors, marketing agents, investment bankers, other potential sources of funding, and suitable legal, accounting, and other professional assistance. It also extends to executing a profitable exit strategy, whether via an IPO, a sale of the entire firm to a third party, or by other means.

\footnotetext{
${ }^{138}$ See generally Sahlman, supra, note 19; Thomas Hellmann and Manju Puri, "Venture Capital and the Professionalization of Start-Up Firms: Empirical Evidence,” (2002), 57 Journal of Finance 169.

${ }^{139}$ Conversation with a partner of Kleiner, Perkins.
} 
Finally, because they hold an equity interest in the firm, ${ }^{140}$ the angel or VC investor has a potent incentive to ensure that the firm is successful. Although a VC manager is merely an intermediary investing other people's money, it will habitually take 20 percent or more of the increase in the value of the fund's portfolio of firms for itself (the so-called carried interest). ${ }^{141}$

Despite this rigorous process of selection and grooming, it is clear that no more than 10 percent of a given VC's investments are home runs - and often only 1 or 2 out of a hundred. ${ }^{142} \mathrm{~A}$ further 20-30 percent are write-offs, and the rest are what VCs often call the "walking wounded" or the "living dead." "143

These figures paint a stark picture of just how difficult it is to pick high-tech winners and losers. If the most skilled private sector investors do so in such a highly imperfect fashion, what can we expect of unskilled and inexperienced government bureaucrats?

\section{Internal Government Decision-Making}

In fact, government bureaucrats lack virtually every aspect of the angel or VC's skill set. Being salaried employees, they lack the high-powered incentives of private investors. They often have no particular technology expertise, whether specific or general, to help them evaluate prospects. They lack the experiential database of the private investor to help them through the process. They do not benefit from the pooling of knowledge that comes from syndicating with others of their ilk, nor are they experts in crafting contracts with their investee firms to incentivize their stable of entrepreneurs. Once the investment is made, they offer their investee firms little or no value-add.

It is doubtful that the incentive problem is amenable to any easy solution, for a number of reasons. The success or failure of a given venture will not be known for a period of time ranging from two or three years to perhaps 10 years or more. However, bonus or merit pay determinations for salaried employees are made on a yearly basis. There is thus a fundamental mismatch between the duration of the investment and the employee's evaluation period.

Efforts to effect an ex-post settling up will be frustrated by the fact that many employees involved in the decision-making process will have changed jobs or even left the government. In addition, because of self-selection, government employees are likely to be more risk averse than the average of the population. There will be little appetite for adjusting compensation expost. Finally, the amount of money at stake, and the proportion that it bears to aggregate income, are small when compared to what is on the line for private investors. Thus, even if an effective ex-post settling-up mechanism could be devised, it would create very low-powered incentives when compared to private investors. ${ }^{144}$

\footnotetext{
${ }^{140}$ This includes convertible debt, or, more often, convertible preferred shares.

${ }^{141}$ Sahlman, supra, note 19.

${ }^{142}$ Cumming and MacIntosh, supra, note 12; John H. Cochrane, "The risk and return of venture capital" (2004), $75 \mathrm{~J}$. Fin. Econ. 3.

${ }^{143}$ Cumming and MacIntosh, supra, note 30.

${ }^{144}$ Ex-post settling up also presents challenging tax issues. For example, the ex-post evaluation process may be so long as to exceed the maximum period during which an income tax return may be adjusted.
} 


\section{Outsourced Evaluation}

Outsourcing the evaluation and/or advice function, as some programs (such as IRAP) do, ${ }^{145}$ bolsters the skill set of the decision-makers. However, it entirely fails to address the incentive problem, since external advisors are fixed rather than residual claimants. Nor can it replicate the experience, breadth of pooled knowledge, or business savvy of private investors.

\section{Academic Peer Review}

As noted earlier, academic peer review works very effectively in the evaluation of basic and applied research. ${ }^{146}$ While it is also a useful adjunct to the evaluation of experimental development projects, a bevy of business issues beyond the competence of academics also come into play.

\section{Co-Investment}

The Jenkins Report's preferred mechanism for direct assistance is co-funding arrangements with angel groups and VCs. ${ }^{147}$ In particular, the panel recommends that the Business Development Corporation (BDC) allocate a larger proportion of its portfolio to start-up financing, and that this should "preferably [be] in the form of a 'sidecar' fund with angel investor groups,", 148 in which the angels contribute at least 50 percent of the funds (and presumably pick the investee firms). This form of direct investment neatly sidesteps some (although not all) of the perils associated with government bureaucrats directly picking winners and losers.

The panel's concern about a dearth of later-stage expansion money is addressed by a similar recommendation, in which government funds are to be co-invested with VCs. The report states that "the market should determine the allocation of financing. Governments should co-invest with private venture capitalists and allow the private investors to determine the investment strategy."

In general, this is a solid foundation upon which to base direct funding. If anything, however, the Panel's recommendation is too modest. Rather than allocating funds from a scaled-back SR\&ED to the BDC to co-invest in angel and venture capital funds, the government should ensure that the common theme of its direct investment in experimental development is reliance on co-investment mechanisms. This will, however, require that the government decide whether it will invest in funds alongside private investors, or in particular projects.

\footnotetext{
${ }^{145}$ See e.g., http://www.nrc-cnrc.gc.ca/eng/ibp/irap/about/advisors.html, discussing the backgrounds and qualifications of IRAP's industrial technology advisors.

${ }^{146}$ Although effective, it is far from perfect. Academic review is sometimes compromised by non-objectivity, since academics in the same or closely cognate fields are natural competitors for promotions, grants, recognition, awards, etc. Even though peer review is typically conducted on a no-names basis, it is frequently not difficult for an academic with a knowledge of the literature and his/her peers' areas of research to guess at the likely identity of the applicant.

${ }^{147}$ See generally Jenkins Report, p.7-17 et seq.

${ }^{148}$ Ibid. p.7-17.

${ }^{149}$ Ibid.
} 


\section{FUND-LEVEL CO-INVESTMENT: THE YOZMA MODEL}

The Jenkins panel's support of co-investment appears to have been inspired by the notable success of Israel's Yozma program. The Israelis virtually built their thriving VC industry from the ground up by contributing 40 percent of the capital to funds otherwise capitalized and controlled by foreign VCs. In these funds, private investors are given the option of repurchasing the government's share at a stated price within five years. Of the 10 funds initially set up, nine exercised their buyout options - and there is presently something like $\$ 10$ billion under management in Israeli VC funds. ${ }^{150}$ The Yozma template has caught on like wildfire in various OECD countries and elsewhere around the world. ${ }^{151}$

The growth of the venture capital industry in Israel, however, was given a kick-start by the arrival of some 750,000 scientists, engineers, and physicians from Russia, as a result of the break-up of the Soviet Union in 1991. ${ }^{152}$ As a consequence, Israel has more scientists and engineers per capita than any other country in the world. ${ }^{153}$ In addition, the Israeli government's considerable military expenditures, like those in the U.S., have made a material contribution to the growth of Israel's high-tech industries.

The modus operandi of a Yozma-style fund is that it lowers the cost of capital for venture capitalists. However, this will not always be of benefit to the local venture capital industry. If the supply of high net present value (NPV) investee firms is limited, the effect of lowering the VC's cost of capital will be to induce the VC to invest in relatively low-quality projects that would not otherwise have been funded - a payoff of questionable value. If, however, there is an abundance of high NPV projects, the VC's choice of investee firms will not change; it will always be better off choosing the highest NPV projects available. In this case, the primary effect of government subsidization will be to enhance the profits of the venture capitalist, without substantially improving the supply of venture capital in the target market.

It would thus seem that a Yozma-style model is justified only if the government believes that VCs are unaware of high-net present-value projects available in the target market and seeks to draw the attention of VCs to these opportunities. It would appear that the latter motive inspired the Yozma program in Israel. The Israeli government sought to attract foreign venture capitalists into the Israeli market, hoping that they would stay once they got there. This appears to have happened. Whether Canada would benefit from such an approach, however, is unclear. American venture capitalists are already investing heavily in Canada, and there does not appear to be any reason to suppose that they fail to appreciate the nature of the market opportunities available here.

Another potentially negative consequence of Yozma-style funding is that funds receiving the benefit of government subsidization, having a lower cost of capital, will routinely outbid other VCs in the target market. This may have the perverse effect of driving non-favoured VCs from the market, potentially reducing, rather than increasing the aggregate supply of venture capital.

\footnotetext{
${ }^{150}$ See http://www.iva.co.il/index.php?option=com_content\&view=article\&id=64\&Itemid=80).

${ }^{151}$ Jenkins Report, p.7-19.

${ }^{152}$ Dan Senor and Saul Singer, Start-up Nation: The Story of Israel's Economic Miracle (Twelve: 2009); Debbie Buchwald, "Israel's High-Tech Boom," II(2) inFocus (Summer 2008), available at http://www.jewishpolicycenter.org/221/israels-high-tech-boom.

${ }^{153}$ Senor and Singer, ibid; Buchwald, ibid.
} 
There is thus reason to believe that the Canadian venture capital market could suffer damage from a Yozma-style program in the long term if: i) there is no shortage of high-NPV projects in Canada; ii) there is no information asymmetry such that foreign VCs are unaware of these opportunities; and iii) foreign venture capitalists are heavily favoured by the Yozma-style program. If all of these conditions hold, then a Yozma-style program will simply subsidize US VCs who would have been investing in Canada in any case. Canadian VCs, with a higher cost of capital, will be driven from the market. When the program is terminated, only US VCs will be left standing; there will be little or no domestic venture capital industry.

One way of addressing this issue is to insist that recipient funds be $\mathrm{VC}$ syndicates with one or more (or perhaps a majority of) Canadian VC partners. This would have the added benefit of exposing Canadian VCs to their generally more sophisticated American counterparts, with a resultant transfer of skills that would benefit the Canadian industry in the long run. By comparison, restricting a Yozma-style program to Canadian VCs could have the unfortunate affect of driving more sophisticated US VCs from the Canadian market, reducing the pool of smart capital available to Canadian entrepreneurs and obviating the benefit of skills transfer. Thus, if the government chooses to adopt the Yozma approach, it would be better to insist that recipient syndicates consist of both Canadian and US VCs.

\section{PROJECT-BY-PROJECT CO-INVESTMENT}

Fund-level investment is not likely to work very effectively in connection with earlier-stage investments with angel investors. While groups of angel investors often participate in Dragon's Den-style vetting of investment projects, investment decisions are typically made on an individual basis. Thus, government co-investment must necessarily be made on a project-byproject basis. This approach will also work for later stage investments alongside venture capitalists or strategic partners.

There are in fact many programs that already adopt this approach, such as the federal government's FedDev Ontario program ${ }^{154}$ and SD Tech Fund. ${ }^{155}$ Such programs have the benefit of allowing well-motivated and skilled private investors to choose which firms receive funding, and make eminently good sense.

\section{The BDC Model: Cloning Private Investment}

The federal government's Business Development Corporation operates on a rather unique model that avoids some of the more difficult issues associated with direct government support of innovation. BDC is organized as a crown corporation with an independent board of directors. As of March 31, 2011, BDC had \$18.4 billion under administration. ${ }^{156}$ Most of this was in the form of debt financing and holdings of asset-backed securities. ${ }^{157}$ However, BDC

\footnotetext{
${ }^{154}$ See http://www.feddevontario.gc.ca/eic/site/723.nsf/eng/home.

${ }^{155}$ See http://www.sdtc.ca/index.php?page=sdtech-funding-niche\&hl=en_CA.

${ }^{156}$ BDC Annual Report 2011, p.9.

${ }^{157}$ Of 3,245 firms supported in 2011, only 365 were investments at the start-up or development stages. Ibid. p.23.
} 
maintains a wholly owned subsidiary - BDC Venture Capital (BDC-VC) - that replicates many features of a private venture capital fund. In particular, BDC-VC hires managers with private sector backgrounds, and rewards its venture managers with a carried interest on the net asset value of the portfolio. ${ }^{158}$

BDC-VC does not, however, replicate all of the advantages of a private fund. It is not, for example, organized as a limited partnership with a limited lifespan. Although, as a crown corporation, it is relatively immune from political interference, it owes its existence to an act of Parliament, ${ }^{159}$ is wholly owned by the government of Canada, finances its activities by borrowing from the government, reports on its activities to the government yearly, is subject to a special examination by the Auditor General of Canada at least once every 10 years, and is ultimately accountable to Parliament via the Minister of Industry. Thus, it is potentially subject to political pressures not experienced by private funds. This may be the reason why the BDC apparently exhibits strong regional preferences in its funding activities.

BDC reports that the fair value of the venture capital portfolio held by BDC-VC was $\$ 407.8$ million as of March 31, 2011, with total venture commitments of $\$ 725.2$, consisting of $\$ 416.5$ of direct investments and $\$ 308.7$ committed to investment funds. BDC Venture Capital thus engages in direct investment as well as acting as a fund of funds.

Overall, BDC's return on equity in 2011 was 9.5 percent; the simple arithmetic average for the past five years is 5.5 percent - well in excess of the LSVCC industry average as well as average returns to Canadian private independent funds. ${ }^{160}$ However, a more telling comparison is with BDC Venture Capital, which has not fared as well. From 2007 to 2011, it incurred losses of \$33.6 million, \$82.8 million, \$106.3 million, \$74.1 million, and \$18.6 million. ${ }^{161}$ These are comparable to or greater than the losses experienced by LSVCCs and private funds. Thus, the jury remains out on the efficacy of this experiment in government-sponsored venture capital.

\section{The Fund-of-Funds Model: Teralys and BDC}

As noted earlier, Solidarity, the Caisse, and Investissement Québec have essentially vacated the venture capital field, collectively entrusting $\$ 1.3$ billion to Teralys, a private fund-of-funds manager. BDC plays a similar role: of $\$ 725.2$ million in funding and funding commitments (as of March 31,2011), nearly 43 percent was placed with other venture capital funds.

\footnotetext{
${ }^{158}$ Conversation with Jean-René Halde, President and CEO, BDC, December 7, 2011.

${ }^{159}$ The BDC was initially incorporated by an act of Parliament on Dec. 20, 1974, as the Federal Business Development Bank. It is currently governed by the Business Development Bank of Canada Act, S.C. 1995, c.28.

${ }^{160}$ According to the CVCA, the net 10-year return realized by private independent funds is -3.1 percent, and the net five-year return is 0.2 percent. See http://www.cvca.ca/files/News/Q2_11_CVCA_Performance_Public_Release_Private_Independent.pdf. Note, however, that the BDC figure is reported as a gross return, while the CVCA reports the returns of private independent funds on a net basis.

161 BDC Annual Report 2011, p.123.
} 
The fund-of-funds approach has much to recommend it. Of all possible mechanisms for spiriting government funds to innovative companies, it comes closest to full privatization. However, since governments are ultimately providing the capital - and thus furnishing their chosen managers with a potentially handsome living - it would be foolish to think that the managers will be completely exempt from political pressures, whether the manager is a governmental entity such as BDC, or an external manager such as Teralys. In addition, the aggregate management fees are higher than in respect of direct investments, since the fund-offunds manager charges a carried interest on top of the carried interest charged by the investee funds. This may be a small price to pay, however, for entrusting government funds to individuals who have both the qualifications and incentives to invest the funds wisely.

\section{PART VI: TAX TREATMENT OF STRATEGIC DISPOSITIONS}

Academic commentary has established the pivotal importance of profitable exit mechanisms in encouraging angel and venture capital investment. ${ }^{162}$ As indicated above in Figure 2, there are two primary exit mechanisms: an initial public offering, and a sale of the entire firm to a strategic acquirer (an M\&A exit). The vast bulk of acquirers in Canadian M\&A exits are American companies.

When an American firm acquires a Canadian company engaged in innovative research, it will often reincorporate the company in the United States, transfer the firm's operations south of the border, or both. The tax burden of selling to a US firm can be considerably greater than that associated with selling to a Canadian firm, distorting the choice of exit vehicle and/or exit partner.

Assume that the sale is effected via a sale of shares. No matter to whom the firm is sold, the sellers (i.e., the early stage investors) will pay capital gains tax on the increase in the value of their shares. However, if the firm is sold to a Canadian entity, the firm itself pays no tax.

By contrast, if the firm is sold to an American acquirer, and the acquirer either reincorporates the firm in the US or moves the assets to the US, a deemed disposition of the firm's assets occurs, on which the firm pays a blend of capital gains and income tax. This materially reduces the US acquirer's after-tax gain from effecting the acquisition. This in turn reduces the price that the acquirer is willing to pay to purchase the firm, which will commensurately reduce the profit earned by the Canadian sellers.

It may be tempting to believe that, as a matter of public policy, it is better to keep innovative assets in Canada, and hence to design a tax system that encourages strategic sales to be effected to Canadian acquirers. However, the reality is that the pool of US acquirers is vastly greater than that of Canadian acquirers. To the extent that US acquirers are allowed low-cost access to Canadian targets, this will tend to increase the returns to innovative activity by Canadians, and commensurately increase the quantum of innovation.

${ }^{162}$ Cumming and MacIntosh, supra, note 12; Gilson and Black, supra, note 91. 


\section{PART VII: SUMMARY AND CONCLUSIONS}

It is time to end the subsidies to LSVCC funds. LSVCCs have generated poor returns, displaced more effective private funds, and in net, have impoverished, rather than enhanced the Canadian venture capital industry.

Private investors and strategic partners do not usually participate in the funding of basic and applied research, leaving government to occupy the field. Because of the importance of basic and applied research in the innovation ecosystem, governments should continue to provide generous funding in these domains, based primarily on academic peer review. In the realm of experimental development, the primary emphasis should be placed on indirect assistance via the SR\&ED credit, supplemented by co-investment with angel (and other) investors.

Later stage direct investment should be based, as the Jenkins Committee suggests, on a coinvestment model. The report is vague, however, on the nature of this co-investment. Care should be taken before adopting a Yozma-style co-investment model. The success of the Yozma program may be the product of a number of factors that are unique to Israel and which do not exist in Canada. There is a danger that a Yozma-style model could actually damage, rather than assist the Canadian venture capital industry. It may be better to proceed on a project-by-project basis in co-funding venture-backed firms.

Limiting the SR\&ED credit paid to CCPCs (but not larger firms) to labour costs, as suggested by the Jenkins Committee, is not likely to result in materially lower application costs for entrepreneurs. It will, however, tilt the playing field in favour of firms with a high labour/capital ratio, create anti-competitive barriers to entry, and penalize firms engaged in manufacturing.

Many of the small firms (typically CCPCs) that currently benefit from SR\&ED funding are engaged in cutting-edge experimental development that forms the roots of the innovation ecosystem. While such research can be expected to have a relatively high failure rate, the paucity of funding sources available to early-stage firms renders the SR\&ED's shotgun approach to funding both warranted and necessary. Many firms engaged in experimental development inhabit a region commonly referred to as the Valley of Death - the early-stage commercialization landscape in which government funding is either absent or ineffective, and private funding largely AWOL. Cutting back on SR\&ED funding could thus inflict grave damage on government efforts to spur innovation - no matter how much money is poured into later-stage commercializations.

The Jenkins Committee's antipathy to the SR\&ED is based, in part, on an overstatement of the target inefficiency of the SR\&EDs, both in absolute terms, and relative to direct investment. The Committee draws upon research by the Department of Finance that shows that only two percent of firms receiving SR\&ED funding become large firms within 5 years of incorporation. The data from which this figure derives are extracted from the post-bubble 2000-2004 period in which returns to small high-tech firms were uncharacteristically poor. Thus, the two percent in five years figure is likely to be unrepresentative of overall growth rates of firms receiving SR\&ED assistance. Comparative data gleaned from the cohort of Silicon Valley firms founded in the year 2000 do not reveal a substantially different growth rate, even though these companies were founded in the world's leading nursery of high-tech firms, and had the benefit of massive (and record-setting) venture capital financing. 
The two percent in five years metric also understates the period of time necessary to bring most high-tech ventures to fruition. It often takes 10 or more years to do so, and many companies that have gone on to great commercial success - such as RIM and E-Ink - were in existence for many years before becoming successful. Added to this, many successful firms - such as those that ultimately licence their technology or are bought out in an M\&A exit will never grow into larger firms.

Recent research suggests that advanced manufacturing is likely to play a vital role in Canada's innovation ecosystem. Advanced manufacturing consists mostly of platform technologies such as nanotechnology, chemistry and biology, which have broad applications across virtually all industrial sectors. The availability of advanced manufacturing facilities offers start-up firms a domestic manufacturing option. This will tend to ensure that successful high-tech firms do not move jobs or production offshore when they reach a scale-up inflection point, allowing foreigners to capture the benefits of domestic investment in innovation.

There is little evidence on how many advanced manufacturing firms Canada currently has, or what proportion of direct government funding reaches such firms. However, many such firms will only adventitiously fall into current funding silos. It is far more likely that these firms will receive support under the SR\&ED program. The government should re-examine its portfolio of assistance programs with a view to ensuring that this sector receives suitable support.

Finally, the federal income tax legislation should be amended so that the sale of an innovative firm to a foreign entity results only in a tax burden on the Canadian sellers that is comparable to the tax burden that would arise if the firm was sold to a Canadian acquirer. 


\section{APPENDIX A: DIRECT ASSISTANCE VARIABLES}

\begin{tabular}{|c|c|c|c|c|c|c|c|c|}
\hline $\begin{array}{l}\text { Form of } \\
\text { Assistance }\end{array}$ & Cash grants & $\begin{array}{l}\text { Restricted cash grants } \\
\text { (e.g., for travel only) }\end{array}$ & Equity & \begin{tabular}{|l|} 
Loan (interest \\
bearing, non-interest \\
bearing, forgivable, \\
non-forgivable, \\
convertible, etc.)
\end{tabular} & $\begin{array}{l}\text { Salary support } \\
\text { (e.g. MITACs, } \\
\text { NSERC) }\end{array}$ & $\begin{array}{l}\text { Non-cash } \\
\text { assistance } \\
\text { (e.g., advice, } \\
\text { networking, } \\
\text { mentoring) }\end{array}$ & $\begin{array}{l}\text { Research (e.g., } \\
\text { NRC institutes) }\end{array}$ & $\begin{array}{l}\text { Fee-based } \\
\text { services (e.g., } \\
\text { NRC institutes) }\end{array}$ \\
\hline $\begin{array}{l}\text { Delivery } \\
\text { Mechanism }\end{array}$ & \begin{tabular}{|l|} 
Direct government \\
administration with \\
full internalization of \\
decision-making
\end{tabular} & $\begin{array}{l}\text { Direct government } \\
\text { administration based } \\
\text { on outside advice } \\
\text { (e.g., IRAP) }\end{array}$ & $\begin{array}{l}\text { Direct government } \\
\text { administration } \\
\text { based on academic } \\
\text { peer review }\end{array}$ & $\begin{array}{l}\text { Co-Investment with } \\
\text { private investors } \\
\text { (angels, VCs, } \\
\text { strategic investors) }\end{array}$ & $\begin{array}{l}\text { Outsourced } \\
\text { institutional (e.g., } \\
\text { Centres of } \\
\text { Excellence) }\end{array}$ & $\begin{array}{l}\text { Government } \\
\text { funded stand- } \\
\text { alone research } \\
\text { institute (e.g., } \\
\text { NRC institutes) }\end{array}$ & $\begin{array}{l}\text { Government- } \\
\text { industry } \\
\text { partnership (e.g., } \\
\text { FP Innovations) }\end{array}$ & $\begin{array}{l}\text { Government } \\
\text { procurement }\end{array}$ \\
\hline $\begin{array}{l}\text { Delivery } \\
\text { Mechanism } \\
\text { (cont'd) }\end{array}$ & $\begin{array}{l}\text { Minority government } \\
\text { investment in private } \\
\text { fund (i.e., Yozma-style } \\
\text { co-investment with } \\
\text { private VCs) }\end{array}$ & $\begin{array}{l}\text { Private-style } \\
\text { government-owned } \\
\text { fund } \\
\text { (e.g., BDC) }\end{array}$ & $\begin{array}{l}\text { Government } \\
\text { investment in fund } \\
\text { of funds (e.g., } \\
\text { Teralys) }\end{array}$ & & & & & \\
\hline $\begin{array}{l}\text { Decision- } \\
\text { Maker }\end{array}$ & \begin{tabular}{|l|} 
Internal bureaucratic \\
determination
\end{tabular} & $\begin{array}{l}\text { Internal determination } \\
\text { supported by external } \\
\text { advice }\end{array}$ & $\begin{array}{l}\text { Academic peer } \\
\text { review }\end{array}$ & $\begin{array}{l}\text { Fund managers } \\
\text { (e.g., BDC) }\end{array}$ & $\begin{array}{l}\text { Investor in } \\
\text { co-investment } \\
\text { arrangement } \\
\text { (e.g., co- } \\
\text { investment with } \\
\text { angels, VCs, } \\
\text { strategic } \\
\text { investors) }\end{array}$ & $\begin{array}{l}\text { Fund of funds } \\
\text { manager, then } \\
\text { fund manager }\end{array}$ & $\begin{array}{l}\text { Institute personnel } \\
\text { (e.g., NRC } \\
\text { research } \\
\text { institutes; joint } \\
\text { government and } \\
\text { industry initiatives; } \\
\text { centres of } \\
\text { excellence) }\end{array}$ & $\begin{array}{l}\text { Government } \\
\text { ministries and } \\
\text { departments } \\
\text { (for government } \\
\text { procurement) }\end{array}$ \\
\hline $\begin{array}{l}\text { Industry } \\
\text { Preference }\end{array}$ & No restrictions & $\begin{array}{l}\text { Single Silo (e.g., FP } \\
\text { Innovations, NRC } \\
\text { Institute for } \\
\text { Aerospace Research, } \\
\text { Strategic Aerospace } \\
\text { and Defence } \\
\text { Initiative, Sustainable } \\
\text { Development } \\
\text { Technology Canada }\end{array}$ & $\begin{array}{l}\text { Multi-silo (e.g., } \\
\text { green, health, etc.) }\end{array}$ & & & & & \\
\hline $\begin{array}{l}\text { Regional } \\
\text { Preference }\end{array}$ & None & $\begin{array}{l}\text { Provincial (provincially } \\
\text { incorporated LSVCCS) }\end{array}$ & $\begin{array}{l}\text { Regional (e.g., } \\
\text { Atlantic Innovation } \\
\text { Fund, Western } \\
\text { Diversification } \\
\text { Program) }\end{array}$ & & & & & \\
\hline $\begin{array}{l}\text { Stage } \\
\text { Preference }\end{array}$ & All & Seed, start-up & Early Stage & Expansion Stage & $\begin{array}{l}\text { Mezzanine } \\
\text { (“mature” in } \\
\text { Jenkins Report) }\end{array}$ & & & \\
\hline Grant Size & $\begin{array}{l}\text { Large grants to a few } \\
\text { recipients }\end{array}$ & $\begin{array}{l}\text { Small grants to many } \\
\text { recipients }\end{array}$ & Intermediate & & & & & \\
\hline $\begin{array}{l}\text { Target } \\
\text { Strategy }\end{array}$ & $\begin{array}{l}\text { Rigorous } \\
\text { determination of } \\
\text { merits (e.g., BDC } \\
\text { venture division) }\end{array}$ & $\begin{array}{l}\text { Loose determination } \\
\text { of merits (e.g., IRAP } \\
\text { advice and } \\
\text { mentoring) }\end{array}$ & & & & & & \\
\hline Recipient & Universities & Small businesses & $\begin{array}{l}\text { Medium-sized } \\
\text { businesses }\end{array}$ & Large businesses & $\begin{array}{l}\text { Not-for-profit } \\
\text { businesses or } \\
\text { institutes }\end{array}$ & $\begin{array}{l}\text { Research } \\
\text { institutes }\end{array}$ & & \\
\hline $\begin{array}{l}\text { Overarching } \\
\text { Goal }\end{array}$ & $\begin{array}{l}\text { Develop innovative } \\
\text { technologies }\end{array}$ & Employment & $\begin{array}{l}\text { Promote university/ } \\
\text { industry/ } \\
\text { government nexus } \\
\text { (e.g., Networks of } \\
\text { Centres of } \\
\text { Excellence, Strategic } \\
\text { Network Grants) }\end{array}$ & $\begin{array}{l}\text { Regional } \\
\text { Development }\end{array}$ & $\begin{array}{l}\text { Fill particular } \\
\text { lacunae in } \\
\text { innovation } \\
\text { ecosystem }\end{array}$ & & & \\
\hline
\end{tabular}




\section{APPENDIX B: COMPARATIVE SKILLS TABLE}

\begin{tabular}{|c|c|c|c|c|c|c|c|c|}
\hline & Angel & Venture Capitalist & Strategic Partner & Gov't Internal & $\begin{array}{l}\text { Gov't Internal } \\
\text { with External } \\
\text { Advice }\end{array}$ & $\begin{array}{c}\text { BDC-Style } \\
\text { Private-Clone } \\
\text { Fund }\end{array}$ & $\begin{array}{l}\text { Teralys-Style } \\
\text { Fund of Funds }\end{array}$ & $\begin{array}{l}\text { Yozma-Style } \\
\text { Co-Investment } \\
\text { (Fund Level) }\end{array}$ \\
\hline $\begin{array}{l}\text { Hands-0n } \\
\text { Experience? }\end{array}$ & Yes & Yes & Yes & No & No & Yes & Yes & Yes \\
\hline $\begin{array}{l}\text { Do Decision- } \\
\text { Makers } \\
\text { Participate in } \\
\text { Firm Success? }\end{array}$ & Yes & Yes & Yes & No & No & Yes & Yes & Yes \\
\hline Compensation & $\begin{array}{l}\text { High Powered } \\
\text { Incentives } \\
\text { - residual claimant } \\
\text { - equity or equity } \\
\text { equivalent }\end{array}$ & $\begin{array}{l}\text { High Powered } \\
\text { Incentives } \\
\text { - carried Interest } \\
\text { (20\% of increase in } \\
\text { value) } \\
\text { - reputation (critical to } \\
\text { raising subsequent } \\
\text { funds) }\end{array}$ & $\begin{array}{l}\text { Medium to High } \\
\text { Powered Incentives } \\
\text { - strategic fit } \\
\text { exploits } \\
\text { technological } \\
\text { synergies } \\
\text { - equity }\end{array}$ & $\begin{array}{l}\text { Low Powered } \\
\text { Incentives } \\
\text { - salaried } \\
\text { employee } \\
\text { - turnover } \\
\text { - absence of } \\
\text { organizational } \\
\text { performance } \\
\text { metrics } \\
\text { - little performance } \\
\text { tracking }\end{array}$ & $\begin{array}{l}\text { Low Powered } \\
\text { Incentives } \\
\text { - fee based } \\
\text { - absence of } \\
\text { performance } \\
\text { metrics } \\
\text { - no performance } \\
\text { tracking }\end{array}$ & $\begin{array}{l}\text { Medium/High } \\
\text { Powered } \\
\text { Incentives } \\
\text { - carried } \\
\text { interest }\end{array}$ & $\begin{array}{l}\text { Fund-of-Funds } \\
\text { Level: Medium- } \\
\text { High Powered } \\
\text { Incentives } \\
\text { - carried interest, } \\
\text { but less than } \\
\text { direct investment } \\
\text { Fund Level: High- } \\
\text { Powered Venture } \\
\text { Capitalist } \\
\text { Incentives }\end{array}$ & $\begin{array}{l}\text { High Powered } \\
\text { Incentives } \\
\text { - carried Interest } \\
\text { ( } 20 \% \text { of } \\
\text { increase in } \\
\text { value) } \\
\text { - reputation } \\
\text { (critical to } \\
\text { raising } \\
\text { subsequent } \\
\text { funds) }\end{array}$ \\
\hline $\begin{array}{l}\text { Limited Fund } \\
\text { Life? }\end{array}$ & $\mathrm{N} / \mathrm{A}$ & Yes & $\mathrm{N} / \mathrm{A}$ & No & No & No & No & Yes \\
\hline $\begin{array}{l}\text { Geographical } \\
\text { Restrictions or } \\
\text { Preferences re } \\
\text { Investments? }\end{array}$ & No & No & No & $\begin{array}{l}\text { If Provincial Funder, } \\
\text { Yes }\end{array}$ & $\begin{array}{l}\text { If Provincial } \\
\text { Funder, Yes }\end{array}$ & Canada & $\begin{array}{l}\text { If Provincial, then } \\
\text { Province }\end{array}$ & $\begin{array}{l}\text { If Provincial, then } \\
\text { Province }\end{array}$ \\
\hline $\begin{array}{l}\text { Are Political } \\
\text { Preferences a } \\
\text { Factor? }\end{array}$ & No & No & No & $\begin{array}{l}\text { Strong, in selection } \\
\text { of investments }\end{array}$ & $\begin{array}{l}\text { Strong, in } \\
\text { selection of } \\
\text { investments }\end{array}$ & $\begin{array}{l}\text { Some (hiring } \\
\text { managers and } \\
\text { signalling } \\
\text { investment } \\
\text { preferences) }\end{array}$ & $\begin{array}{l}\text { Some risk of } \\
\text { signalled political } \\
\text { preferences }\end{array}$ & No \\
\hline $\begin{array}{l}\text { Alignment of } \\
\text { Time Horizon? }\end{array}$ & Yes & Yes & Yes & $\begin{array}{l}\text { No (one year } \\
\text { evaluation cycle for } \\
\text { employees) }\end{array}$ & No & Yes & $\mathrm{N} / \mathrm{A}$ & N/A \\
\hline $\begin{array}{l}\text { Technology- } \\
\text { Specific } \\
\text { Expertise? }\end{array}$ & $\begin{array}{l}\text { Yes } \\
\text { - State of Technology } \\
\text { - Competitive } \\
\text { Landscape } \\
\text { - Customers } \\
\text { - Suppliers } \\
\text { - Strategic Partners } \\
\text { - Marketing Channels }\end{array}$ & $\begin{array}{l}\text { Yes } \\
\text { - State of Technology } \\
\text { - Competitive } \\
\text { Landscape } \\
\text { - Customers } \\
\text { - Suppliers } \\
\text { - Strategic Partners } \\
\text { - Marketing Channels }\end{array}$ & $\begin{array}{l}\text { Yes } \\
\text { - State of Technology } \\
\text { - Competitive } \\
\text { Landscape } \\
\text { - Customers } \\
\text { - Suppliers } \\
\text { - Strategic Partners } \\
\text { - Marketing Channels }\end{array}$ & No & Middling & Yes & No & $\begin{array}{l}\text { Yes } \\
\text { - State of } \\
\text { Technology } \\
\text { - Competitive } \\
\text { Landscape } \\
\text { - Customers } \\
\text { - Suppliers } \\
\text { - Strategic } \\
\text { Partners } \\
\text { - Marketing } \\
\text { Channels }\end{array}$ \\
\hline
\end{tabular}


APPENDIX B: COMPARATIVE SKILLS TABLE (CONT'D)

\begin{tabular}{|c|c|c|c|c|c|c|c|c|}
\hline & Angel & Venture Capitalist & Strategic Partner & Gov't Internal & $\begin{array}{l}\text { Gov't Internal } \\
\text { with External } \\
\text { Advice }\end{array}$ & $\begin{array}{l}\text { BDC-Style } \\
\text { Private-Clone } \\
\text { Fund }\end{array}$ & $\begin{array}{l}\text { Teralys-Style } \\
\text { Fund of Funds }\end{array}$ & $\begin{array}{l}\text { Yozma-Style } \\
\text { Co-Investment } \\
\text { (Fund Level) }\end{array}$ \\
\hline $\begin{array}{l}\text { Specialized } \\
\text { Evaluation } \\
\text { Skills? }\end{array}$ & Yes & Yes & Yes & No & Middling & Yes & Yes & Yes \\
\hline $\begin{array}{l}\text { Screening } \\
\text { Process }\end{array}$ & $\begin{array}{l}\text { - business associates } \\
\text { - contacts } \\
\text { - rigorous due } \\
\text { diligence } \\
\text { - syndicate to pool } \\
\text { expertise }\end{array}$ & $\begin{array}{l}\text { - pre-screen } \\
\text { - post-screen due } \\
\text { diligence, funding } \\
1-2 \text { out of } 100 \\
\text { - syndicate to pool } \\
\text { expertise }\end{array}$ & $\begin{array}{l}\text { - trade shows } \\
\text { - technical } \\
\text { publications } \\
\text { - published patents } \\
\text { - rigorous due } \\
\text { diligence }\end{array}$ & Internal & $\begin{array}{l}\text { Individual or } \\
\text { Multiple }\end{array}$ & $\begin{array}{l}\text { - pre-screen } \\
\text { - post-screen } \\
\text { due diligence, } \\
\text { funding } 1-2 \\
\text { out of } 100 \\
\text { - syndicate to } \\
\text { pool expertise }\end{array}$ & $\begin{array}{l}\text { Screening of } \\
\text { Funds }\end{array}$ & $\begin{array}{l}\text { - pre-screen } \\
\text { - post-screen due } \\
\text { diligence, } \\
\text { funding } 1-2 \text { out } \\
\text { of } 100 \\
\text { - syndicate to } \\
\text { pool expertise }\end{array}$ \\
\hline $\begin{array}{l}\text { Survivorship Bias } \\
\text { (i.e. market } \\
\text { culling of } \\
\text { unsuccessful } \\
\text { operators)? }\end{array}$ & Yes & Yes & Yes & No & No & $\begin{array}{l}\text { No (although } \\
\text { subject to gov't } \\
\text { dictated } \\
\text { changes in } \\
\text { funding) }\end{array}$ & No & Yes \\
\hline $\begin{array}{l}\text { Active } \\
\text { Monitoring? }\end{array}$ & $\begin{array}{l}\text { Yes } \\
\text { - directorship } \\
\text { - informal contact } \\
\text { - staging } \\
\text { - syndication } \\
\text { - contractual levers }\end{array}$ & $\begin{array}{l}\text { Yes } \\
\text { - directorship } \\
\text { - informal contact } \\
\text { - staging } \\
\text { - syndication } \\
\text { - contractual levers }\end{array}$ & $\begin{array}{l}\text { Yes } \\
\text { - informal contacts } \\
\text { - staging with } \\
\text { rigorous } \\
\text { performance } \\
\text { targets }\end{array}$ & $\begin{array}{l}\text { No/Weak } \\
\text { - staging with } \\
\text { performance } \\
\text { targets } \\
\text { - directorship } \\
\text { (sometimes) }\end{array}$ & No & Yes & $\mathrm{N} / \mathrm{A}$ & $\begin{array}{l}\text { Yes } \\
\text { - directorship } \\
\text { - informal contact } \\
\text { - staging } \\
\text { - syndication } \\
\text { - contractual } \\
\text { levers }\end{array}$ \\
\hline $\begin{array}{l}\text { General } \\
\text { Business Skills }\end{array}$ & $\begin{array}{l}\text { Yes } \\
\text { - management } \\
\text { - financial } \\
\text { management } \\
\text { - professional } \\
\text { contacts (e.g., } \\
\text { lawyers, } \\
\text { accountants, patent } \\
\text { agents, managers) } \\
\text { - other sources of } \\
\text { financing }\end{array}$ & $\begin{array}{l}\text { Yes } \\
\text { - management } \\
\text { - financial } \\
\text { management } \\
\text { - professional } \\
\text { contacts (e.g., } \\
\text { lawyers, } \\
\text { accountants, patent } \\
\text { agents, managers) } \\
\text { - other sources of } \\
\text { financing }\end{array}$ & $\begin{array}{l}\text { Yes } \\
\text { - management } \\
\text { - financial } \\
\text { management } \\
\text { - full suite of } \\
\text { commercialization } \\
\text { skills }\end{array}$ & No & No & Yes & Yes & $\begin{array}{l}\text { Yes } \\
\text { - management } \\
\text { - financial } \\
\text { management } \\
\text { - professional } \\
\text { contacts (e.g., } \\
\text { lawyers, } \\
\text { accountants, } \\
\text { patent agents, } \\
\text { managers) } \\
\text { - other sources of } \\
\text { financing }\end{array}$ \\
\hline $\begin{array}{l}\text { Expertise in } \\
\text { Engineering and } \\
\text { Timing Exit? }\end{array}$ & Yes & Yes & N/A & No & No & Yes & $\mathrm{N} / \mathrm{A}$ & Yes \\
\hline
\end{tabular}




\section{APPENDIX C: COMPARATIVE SKILLS TABLE FOR FUNDS-OF-FUNDS}

\begin{tabular}{|c|c|c|c|c|}
\hline & $\begin{array}{c}\text { Teralys-Style } \\
\text { Fund-of-Funds: } \\
\text { Fund-of Funds-Level }\end{array}$ & $\begin{array}{l}\text { Teralys-Style Fund-of- } \\
\text { Funds: Fund Level } \\
\text { ("VC" = same as VC) }\end{array}$ & $\begin{array}{c}\text { Yozma-Style } \\
\text { Co-Investment } \\
\text { (Government Level) }\end{array}$ & $\begin{array}{c}\text { Yozma-Style } \\
\text { Co-Investment: Fund Level } \\
\text { ("VC" = same as VC) }\end{array}$ \\
\hline $\begin{array}{l}\text { Do Decision-Makers Participate } \\
\text { in Firm Success? }\end{array}$ & Yes & VC & No & VC \\
\hline Compensation & $\begin{array}{l}\text { Medium Powered } \\
\text { Incentives } \\
\text { - carried interest, but less } \\
\text { than direct investment }\end{array}$ & VC & $\begin{array}{l}\text { Salaried Political or } \\
\text { Administrative Officials }\end{array}$ & VC \\
\hline Limited Fund Life? & $\mathrm{N} / \mathrm{A}$ & VC & No & VC \\
\hline $\begin{array}{l}\text { Geographical Restrictions or } \\
\text { Preferences re Investments? }\end{array}$ & Yes & Yes & Yes & Yes \\
\hline $\begin{array}{l}\text { Are Political Preferences Likely } \\
\text { to be a Factor? }\end{array}$ & Yes & Yes & Yes & Yes \\
\hline Alignment of Time Horizon? & $\mathrm{N} / \mathrm{A}$ & VC & $\mathrm{N} / \mathrm{A}$ & VC \\
\hline Technology-Specific Expertise? & $\mathrm{N} / \mathrm{A}$ & VC & $\mathrm{N} / \mathrm{A}$ & VC \\
\hline Specialized Evaluation Skills? & $\mathrm{N} / \mathrm{A}$ & VC & $\mathrm{N} / \mathrm{A}$ & VC \\
\hline Screening Process & $\mathrm{N} / \mathrm{A}$ & VC & $\mathrm{N} / \mathrm{A}$ & VC \\
\hline $\begin{array}{l}\text { Survivorship Bias (i.e. market } \\
\text { culling of unsuccessful } \\
\text { operators)? }\end{array}$ & No & VC & No & VC \\
\hline Active Monitoring? & $\mathrm{N} / \mathrm{A}$ & VC & $\mathrm{N} / \mathrm{A}$ & VC \\
\hline General Business Skills & Yes & VC & Maybe & VC \\
\hline $\begin{array}{l}\text { Expertise in Engineering and } \\
\text { Timing Exit? }\end{array}$ & $\mathrm{N} / \mathrm{A}$ & VC & $\mathrm{N} / \mathrm{A}$ & VC \\
\hline
\end{tabular}




\section{ABOUT THIS PUBLICATION}

The School of Public Policy Research Papers provide in-depth, evidence-based assessments and recommendations on a range of public policy issues. Research Papers are put through a stringent peer review process prior to being made available to academics, policy makers, the media and the public at large. Views expressed in The School of Public Policy Research Papers are the opinions of the author(s) and do not necessarily represent the view of The School of Public Policy.

\section{OUR MANDATE}

The University of Calgary is home to scholars in 16 faculties (offering more than 80 academic programs) and 36 Research Institutes and Centres including The School of Public Policy. Under the direction of Jack Mintz, Palmer Chair in Public Policy, and supported by more than 100 academics and researchers, the work of The School of Public Policy and its students contributes to a more meaningful and informed public debate on fiscal, social, energy, environmental and international issues to improve Canada's and Alberta's economic and social performance.

The School of Public Policy achieves its objectives through fostering ongoing partnerships with federal, provincial, state and municipal governments, industry associations, NGOs, and leading academic institutions internationally. Foreign Investment Advisory Committee of the World Bank, International Monetary Fund, Finance Canada, Department of Foreign Affairs and International Trade Canada, and Government of Alberta, are just some of the partners already engaged with the School's activities.

For those in government, The School of Public Policy helps to build capacity and assists in the training of public servants through degree and non-degree programs that are critical for an effective public service in Canada. For those outside of the public sector, its programs enhance the effectiveness of public policy, providing a better understanding of the objectives and limitations faced by governments in the application of legislation.

\section{DISTRIBUTION}

Our publications are available online at www.policyschool.ca.

\section{DISCLAIMER}

The opinions expressed in these publications are the authors' alone and therefore do not necessarily reflect the opinions of the supporters, staff, or boards of The School of Public Policy.

\section{COPYRIGHT}

Copyright (C) 2012 by The School of Public Policy.

All rights reserved. No part of this publication may be reproduced in any manner whatsoever without written permission except in the case of brief passages quoted in critical articles and reviews.

\section{ISSN}

1919-112x SPP Research Papers (Print) 1919-1138 SPP Research Papers (Online)

\section{DATE OF ISSUE}

March 2012

\section{MEDIA INQUIRIES AND INFORMATION}

For media inquiries, please contact Morten Paulsen at 403-453-0062.

Our web site, www.policyschool.ca, contains more information about The School's events, publications, and staff.

\section{DEVELOPMENT}

For information about contributing to The School of Public Policy, please contact Courtney Murphy by telephone at 403-210-7201 or by e-mail at cmurphy@ucalgary.ca.

\section{EDITOR}

Timothy Giannuzzi
Sponsored by

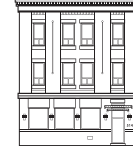

\section{MANNING FOUNDATION \\ FOR DEMOCRATIC EDUCATION}




\section{RECENT PUBLICATIONS BY THE SCHOOL OF PUBLIC POLICY}

DEPARTURES FROM NEUTRALITY IN CANADA'S GOODS AND SERVICES TAX

http:// policyschool.ucalgary.ca/?q=content/ departures-neutrality-canadas-goods-and-services-tax.pdf Michael Smart | February 2012

SOME OBSERVATIONS ON THE CONCEPT AND MEASUREMENT OF INCOME INEQUALITY http:// policyschool.ucalgary.ca/sites/default/files/research/richardson-comm2.pdf Stephen R. Richardson | February 2012

A REVIEW AND ASSESSMENT OF PRIVATIZATON IN CANADA

http:/ / policyschool.ucalgary.ca/sites/ default/files/research/boardman-vining-privatization.pdf Anthony E. Boardman and Aidan R. Vining | January 2012

THE INTERNATIONAL EXPERIENCE WITH PRIVATIZATION: ITS RAPID RISE, PARTIAL FALL AND UNCERTAIN FUTURE

http:// policyschool.ucalgary.ca/ sites/default/files/research/nellis-privatization.pdf

John Nellis | January 2012

HOUSING SUBSIDIES AND HOMELESSNESS: A SIMPLE IDEA

http:/ / policyschool.ucalgary.ca/ sites/ default/files/research/oflaherty-housing-subsidy.pdf

Brendan O'Flaherty | January 2012

PUBLIC SECTOR WAGE GROWTH IN ALBERTA

http:/ / policyschool.ucalgary.ca/ sites/default/files/research/boesenkool-public-wage-growth.pdf Ken Boessenkool and Ben Eisen | January 2012

CATCHING THE BRASS RING: OIL MARKET DIVERSIFICATION POTENTIAL FOR CANADA http:/ / policyschool.ucalgary.ca/ sites/default/files/ research/mmoore-oilmarket.pdf M.C. Moore, S. Flaim, D. Hackett, S. Grissom, D. Crisan and A. Honarvar | December 2011

THE CONSTITUTIONALITY OF FEDERAL CLIMATE CHANGE LEGISLATION

http:/ / policyschool.ucalgary.ca/ ?q=content/constitutionality-federal-climate-change-legislation

Alastair Lucas and Jenette Yearsley | December 2011

THE MYTHS AND FACTS OF FOSSIL FUEL SUBSIDIES: A CRITIQUE OF EXISTING STUDIES

http:/ / policyschool.ucalgary.ca/files/ publicpolicy/MCKENZIE\%20MINTZ\%20online.pdf

Kenneth J. McKenzie and Jack M. Mintz | October 2011

HOMELESSNESS IN ALBERTA: THE DEMAND FOR SPACES IN ALBERTA'S HOMELESS SHELTERS

http:/ / policyschool.ucalgary.ca/files/ publicpolicy/ homelessness\%20in\%20alberta.pdf

Ronald Kneebone, J.C. Herbert Emery and Oksana Grynishak | September 2011

THE NEW SECURITY PERIMETER WITH THE UNITED STATES

http:/ / policyschool.ucalgary.ca/files/ publicpolicy/flemming\%20sept011.pdf

Brian Flemming | September 2011

INCOME SUPPORT FOR PERSONS WITH DISABILITIES

http:// policyschool.ucalgary.ca/files/publicpolicy/Kneebone_Disability_Study.pdf

Ronald Kneebone and Oksana Grynishak | September 2011

INVESTMENT REVIEW IN CANADA - WE CAN DO BETTER

http:/ / policyschool.ucalgary.ca/files/publicpolicy/Herman\%20Invest\%20Canada\%20online.pdf

Lawrence L. Herman | September 2011 